\title{
"From Baby's First Bath": Kaō Soap and Modern Japanese Commercial Design
}

\section{Gennifer Weisenfeld}

When Nagase Tomirō opened his Western sundries shop in Tokyo in 1887, cosmetic soap used for the face and body was not commonly seen in the average Japanese household, and in Japan neither hand washing nor hair washing was the general custom that each is today. ${ }^{1}$ Now known as Kaō Corporation, the company Nagase founded is one of the leaders in the Japanese health and beauty industry, having played a central role in the transformation of the daily hygiene and cosmetic practices of the Japanese nation over the last century. Kaō's contribution to modern Japanese culture goes beyond the sphere of daily life, as the company was also a vital sponsor of some of the most pioneering graphic design of the prewar period. Kaō is widely recognized by Japanese design historians for its impact on the development of modern Japanese advertising design, and the company's promotional materials are regularly included in historical surveys and museum exhibitions. ${ }^{2}$ However, there has been little systematic attempt to analyze this advertising production within a comprehensive context of world design history that takes into account the wide-ranging cultural implications of Japan's consumer capitalism and the ideological formations of Japanese nation- and empire-building.

I propose to integrate the disparate scholarly spheres of art, design, business, social, and political history, reading aesthetics back into the sociology of consumption. I consider Kaō as an innovative and adaptive producer in the sphere of Japanese visual culture and explore how the integration of high art, particularly modernist aesthetics, into commercial advertising allowed the company to distinguish its brandname products. To this end, following a brief history of the company's early development and promotional activity, I concentrate on its operations during the 1930s. This was when Kaō launched an important advertising campaign under the banner "New and Improved Kaō," deploying a stunning and unprecedented array of modernist pictorial techniques to redefine Kaō soap's brand identity from a luxury item to a mass-market consumer good. Applications of modernism in this instance, while keyed to the democratization of soap, enabled Kaō to preserve its product's elite cultural cachet and stylishness.

Kaō designs show strong parallels with the major artistic movements in the world of fine arts. These include employing abstracted or nonobjective forms, as well as nonmimetic photographic techniques such as photomontage and the photogram, which drew inspiration from cutting-edge work abroad by a long list of artist-designers headed by Herbert Bayer, László Moholy-Nagy, Herbert Matter, Aleksandr Rodchenko, El Lissitzky, Fernand Léger, and Man Ray. It is my contention that Kaō designers were able to maximize the marketing effectiveness of their advertising compositions through the skillful application of modernist pictorial techniques, which highlighted product special features and criti- cal elements of brand identity. In the following analysis of Kaō's advertising designs, I will tease out the individual applications of these formal strategies. Examining how and why various images were used to further specific promotional goals, I will also interrogate the larger social and political framework in which they were deployed.

A study of Kaō's commercial design offers an invaluable opportunity to reexamine the important relationship between high art and mass culture in Japan. In the six decades since critic Clement Greenberg, in his now-notorious 1939 manifesto "Avant-Garde and Kitsch," articulated the profound abhorrence felt by modernists concerning the possible "contamination" of pure form with matters of function and commerce, countless scholars have demonstrated modernism's utter failure at aesthetic autonomy, revealing the deep anxieties embodied in the formalist critiques that anathematized mass culture. In these critiques, mass culture was often gendered female because of the popular association between women and consumption, yielding a means of masculinizing and heroicizing elitist forms of artistic practice. ${ }^{3}$ Discrediting mass culture through "sexualized metaphors," which stand for intangible social relations, has also had the effect of obscuring the profound role of aesthetics in constituting the "symbolic and social dimensions of consumption."4

Little attention has been paid to issues of gender in relation to Japanese commercial design, but work in related areas proves highly pertinent. The social historian Narita Ryūichi has explored the gendered nature of the emerging modern discourse on hygiene (eisei) in Japan, which I believe provides a crucial analytical framework for understanding how, and to whom, soap manufacturers marketed newly constructed rituals of cleanliness. ${ }^{5}$ Narita has shown that from 1900 to 1930 , when modern hygiene information was widely disseminated in Japan, the home was the primary locus of daily attention to hygiene, and women were designated by official and nonofficial sources, including neighborhood associations and the mass media, the chief managers of this domestic sphere. Women's active contributions to public forums on matters of hygiene, such as question-and-answer sections in popular journals, indicate their continued concern with these issues and their gradual assimilation of institutionalized notions of a healthy ("normal") body. ${ }^{6}$

Kaō targeted several consumer groups, with upper- and middle-class urban women initially constituting the major portion of the company's national consumer base. In the process of democratization, the target clientele was expanded to include blue-collar women and their families. Advertising was integral to the creation of a national society, and advertisers stood among a range of competing interests, both public and private, that were attempting to mold the sphere of women. I will argue that the mobilization of women in the construction of new concepts and practices of modern living 


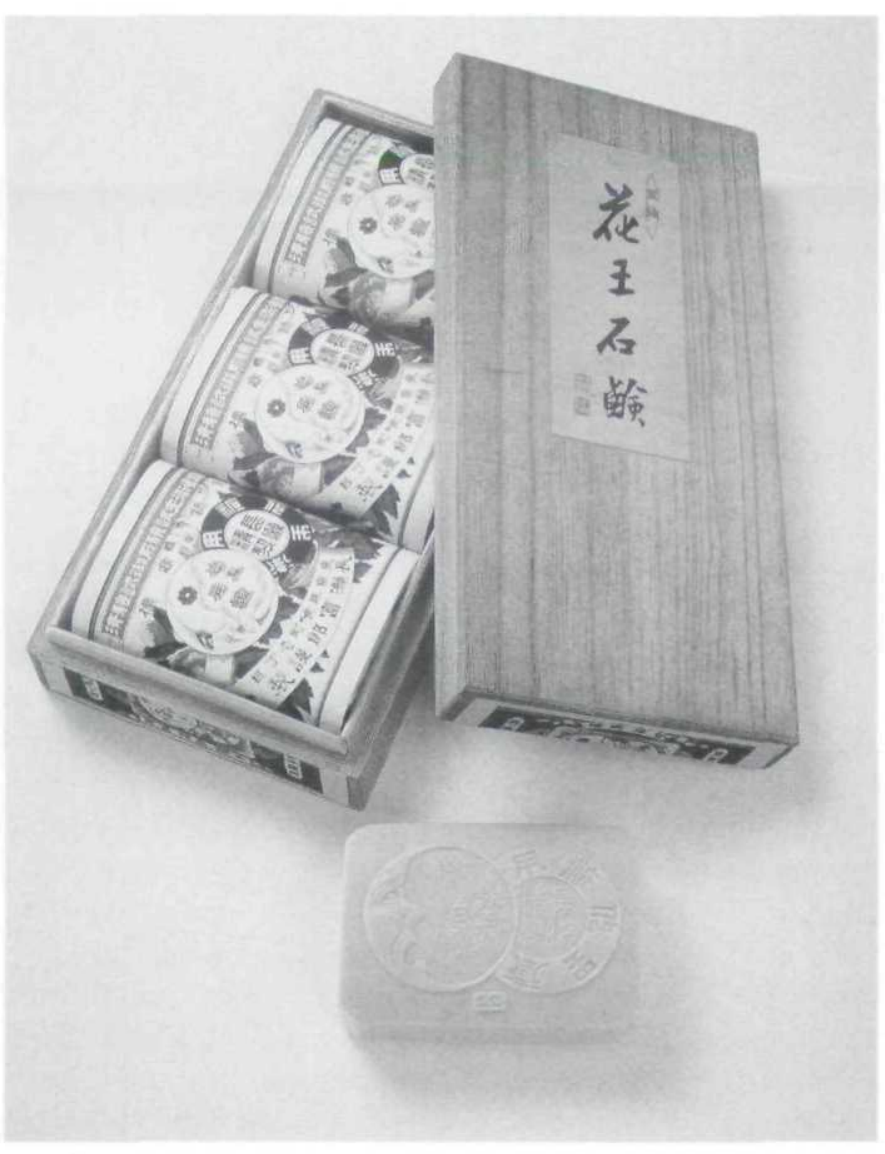

1 Kaō soap bar and three-bar box, 1890. Tokyo, Kao Corporation

in Japan intertwined aesthetics, domestic hygiene, and national identity. I should say outright, however, that my intention here is not to revisit or resolve the scholarly debate about whether mass consumerism was controlling or emancipatory for women, as I believe it was simultaneously both. Rather, I seek to examine the interplay between aesthetics in corporate advertising design and changing social formations as gender roles were constructed and debated in the public sphere.

\section{The Early History of Kaō Soap}

Nagase Tomirō, the company's founder and first president, began marketing Kaō brand soap (kā sekken)-one of the earliest domestically produced brands of cosmetic soap-in 1890 , and by 1910 it was a national brand. ${ }^{7}$ At the time, relatively few products had brand-name recognition-even fewer had national recognition-and merchant identity was often more a selling point than that of the manufacturer. Commonly called savon in Japan from the mid-sixteenth century, soon after its introduction by European traders, soap was used for mainly medicinal purposes by only a small sector of the Japanese population, with the majority of people using forms of rice bran, pumice, and loofah for washing. With the importation of mass-produced, higher-quality soaps in the late nineteenth century, cosmetic soap for the face and body began to be marketed to a broader array of upper-class consumers for about 5 sen per bar, while no-name domestic soap of lower quality was sold for 10 sen per dozen and a five-kilogram bag of rice sold for 23 sen (there are 100 sen in one yen). Because of its relatively high cost of production, Kaō soap was marketed as a luxury and gift item, selling initially for a steep 12 sen per bar, with gift boxes of three priced at 35 sen. $^{8}$ Even by 1926, however, the average monthly household income for laborers was still only 102.07 yen, of which nearly a third went for food and another 50 percent went for nonfood expenditures, including housing. A little over 7 percent, or 7.37 yen, was designated for medical and hygiene expenses. ${ }^{9}$ At the same time, the average household income for salaried workers, at 137.17 yen, was not much higher, with close to a third spent on food and over 60 percent for nonfood expenditures, with just a slightly higher portion devoted to medical and hygiene expenses. The small margin of disposable income indicates the relative luxury of purchasing name-brand cosmetic soap at the time. ${ }^{10}$

The high profit margin on cosmetic goods was a major incentive for manufacturers, although initially half of this profit was cycled back into advertising. ${ }^{11}$ Nagase composed all the early copy and layouts for Kaō promotional material. He was a close friend of American F. W. Eastlake, founder of Tōkyō Eigo Gakuin (Tokyo English Academy) in 1890, and Eastlake was a crucial source for up-to-date examples of advertising from Europe and the United States. From the beginning, soap's image, name, and packaging were considered of preeminent importance in its effective marketing to the Japanese, who were not accustomed to purchasing this product. Early advertisements concentrated on featuring the product itself, emphasizing its unsurpassed quality, hygienic and cosmetic efficacy, and modern stylishness. ${ }^{12}$ Each bar of soap was imprinted with the company name and distinctive logo. Bars were then individually wrapped in decorated paper that once again featured the company name and logo imprinted in black, green, and gold. Popular three-bar sets were further packaged in an upscale paulownia wood box (Fig. 1).

At the time Kaō entered the market, regular lower-grade soap was referred to as arai sekken (cleaning soap), while more refined (often scented) cosmetic soap was known as kao arai (kao, meaning "face," and arai, meaning "to clean"). Desiring to associate the company's domestically produced soap with cosmetic applications for the face, Nagase Tomirō experimented with a variety of homophones for the word face (kao) when selecting characters for the product brand-name. Advertising copy announcing the product launch explained that the combination of the characters for flower ( $($ t $)$ and king (王), creating the sound "ka-ō," referred to the pristine beauty and heavenly fragrance of the peony, commonly known as the "king of a hundred flowers." Chinese poets such as Li Bai, the text went on to explain, associated the peony with the legendary Tang dynasty beauty Yang Gui Fei (719-756), who was immortalized in the poetry of Bo Juyi for her fair, snow white complexion-a complexion that use of the Kaō product promised to help reproduce. ${ }^{13}$ As a result, this poetic, Sinicized brand-name aurally evoked the majestic image of a clean and beautiful face and served as an inspiration for the pictorial and typographic expression of company designers. The calligraphic brand-name typography was later codified and used everywhere, including promotional delivery trucks, billboards along railway lines, and electrically illuminated signboards on top of city buildings. ${ }^{14}$ 
2 Evolution of Kaō soap crescent moon logo from 1890 to 1925 . Tokvo, Kao Corporation
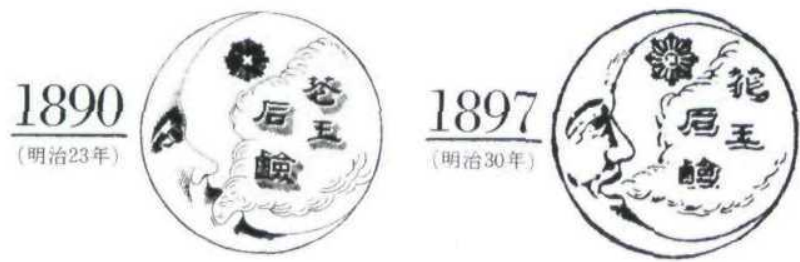
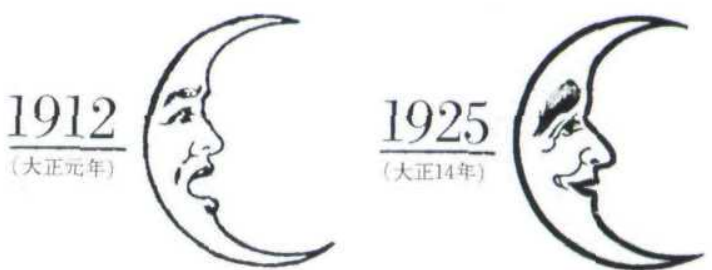

Nagase reinforced the Kaō brand identity as a facial cosmetic product by choosing for the company trademark the image of a crescent moon with a face uttering the words "kaō soap" in a cloud of bubbles (Fig. 2). Pictorial images associated with shining were consistently popular for use in trademarks in Japan because they were thought to imbue commercial products with auspicious associations, specifically, the illumination of heaven and the gods. ${ }^{15}$ Most such images included one of the "three shining symbols" of the moon, star, and sun. While Nagase is credited with selecting the crescent moon logo (which was initially combined with a star), in fact, a number of years prior to his registration of the Kao logo, the image was already associated with imported soaps, most notably the popular product Ivory soap, marketed widely by Proctor and Gamble from 1879. The crescent moon was also associated with the cycles of the month and, by extension, the ocean tides and women. It became a common feature in the trademarks of companies in the pharmaceutical and cosmetic industries, particularly for products related to hygiene. ${ }^{16}$ The physiognomy of the face in Kaō's crescent moon logo changed over time, becoming slightly more wizened and approachable by the mid-1920s. ${ }^{17}$

The brand-name and the crescent moon logo have been two common sites of typographic and pictorial elaboration in company advertising throughout its history. Already representing an image of the man in the moon, the logo was further anthropomorphized in early company advertising in the Meiji period (1868-1912), which showed the crescent moon face engaged in various activities. The moon face was placed on an array of human bodies: a kneeling samurai in traditional Japanese male attire extolling the product's superior hygienic efficacy (Fig. 3) or a standing figure nattily dressed in a Western-style morning coat offering New Year's greetings in a cloud of bubbles (Fig. 4). On the back cover of publisher Hakubunkan's serial publication Nichiro sensō jikki (Actual accounts of the Russo-Japanese War) published in 1904, a Kaō advertisement shows a disembodied crescent moon face floating over a globe and reading from a book that extols the urgent need for Kaō soap's high quality during wartime, when, as the copy reminds the reader, matters of hygiene and economics are of utmost importance (Fig. 5). This necessity implicitly extended to Japan's imperialist expansion (an expanding dominion signified by the moon over the globe), as the war was being fought over contested holdings in northern China that would eventually become the foothold for the establishment of Manchukuo, a Japanese puppet-state colony in Manchuria in 1931. The connection between hygiene, economics, and national standing in the theater of world imperialism was a theme revisited in subsequent promotional campaigns.

By 1930, there were over 17 million women between the

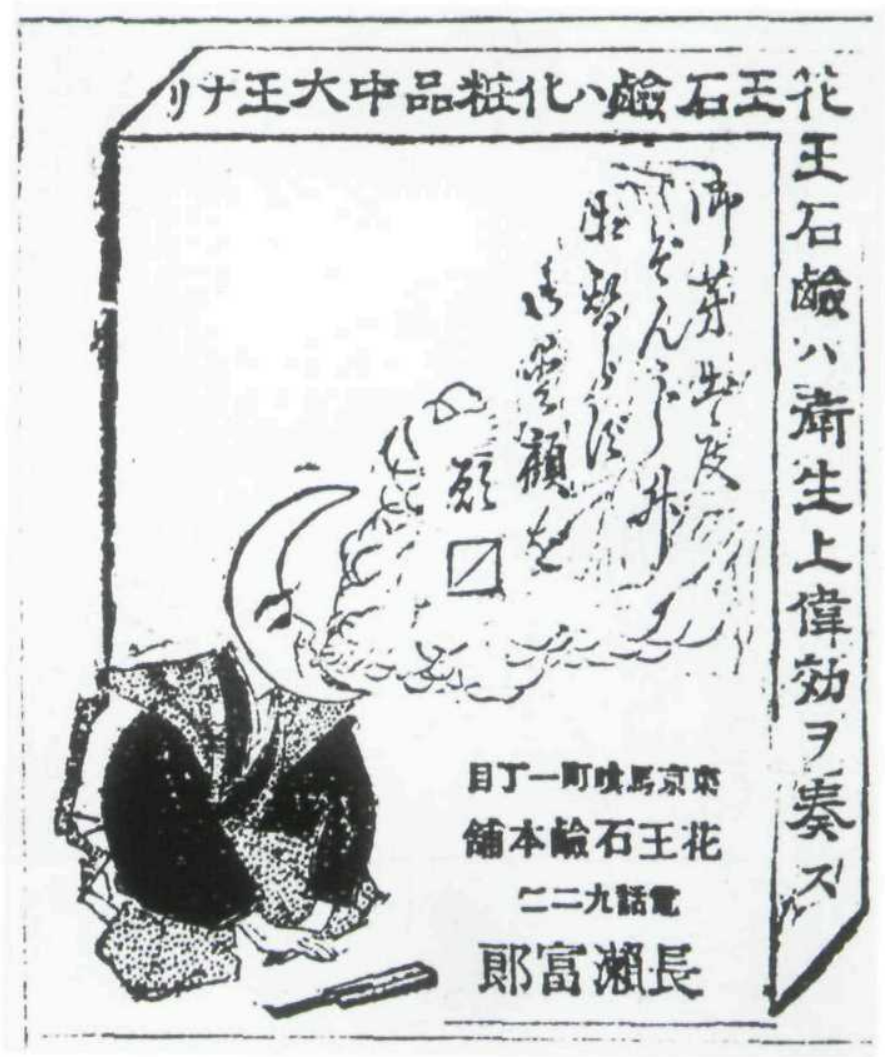

3 Kaō soap advertisement, source unknown, 1894. Tokyo, Kao Corporation

ages of fifteen and sixty-four in Japan, and even the limited marketing data available from the prewar period indicates the importance of women consumers as a market for new Western-style health and beauty products like soap. ${ }^{18}$ Keen to attract this large pool of consumers, Kaō Soap Corporation and many other corporate advertisers found it beneficial to link their marketing strategies to the public policy objectives of the patriarchal Japanese state, which was already engaged in an effort to mold women of varying ages into educated consumer subjects. State and social reformers of often surprisingly different political persuasions were involved in a broad-based national movement to make women into efficient domestic managers (modern housewives) and hygienic, rational mothers, an ideal represented by the highly moralizing slogan of the period, "good wife, wise mother." Historian Sheldon Garon has dubbed these interventions a form of "social management," which was increasingly evident across Japanese society through the 1920 s and intensified in the 1930 s as imperial subjects were mobilized in "moral suasion" campaigns. ${ }^{19}$

As a commodity, cosmetic soap straddled the line between 


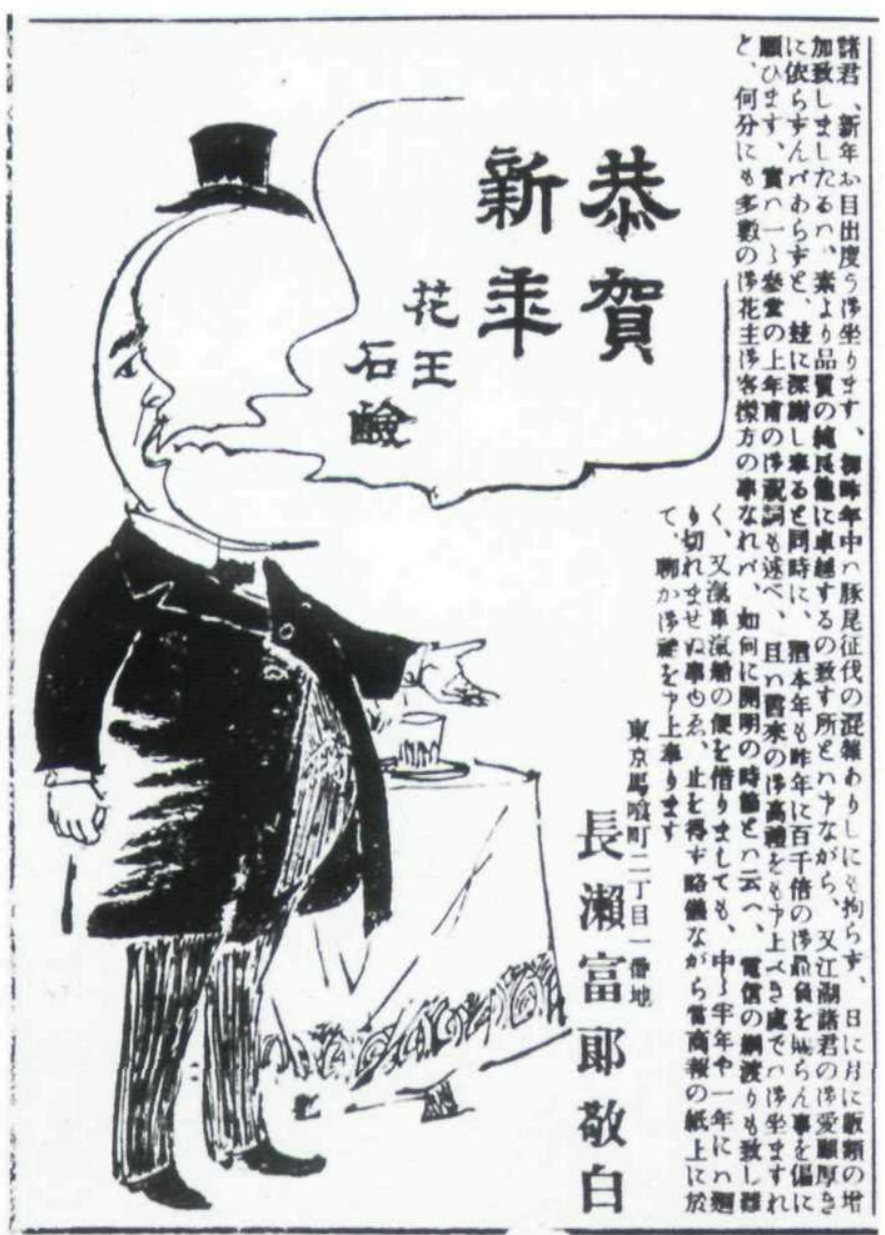

4 Kaō soap advertisement, from Tokyo komamono keshōhin shōhō [Sundries and Cosmetic Industry News], Jan. 1, 1896. Tokyo, Kao Corporation

health and beauty, revealing a dual identity allied to both practical hygiene and luxury consumption. This is borne out in Kaō's multipronged marketing strategy from the product's inception, which advocated regular soap use as the first line of defense against the transmission of disease while simultaneously promoting it as the key to beautiful skin. Kaō products were sold at upscale and everyday retail establishments catering to a broad range of women from housewives to working women, including, of course, their extended families. ${ }^{20}$

A Kaō advertisement from March 1930 that appeared in many major national newspapers rendered in the style of a simple, roughly hewn wood-block print shows the head of a modern young woman, identifiable by her up-to-date bun hairstyle and her clearly Westernized features. The copy text is literally embedded in her otherwise empty head. It reads, "If you were to ask the doctor you most trust, the first thing he would say is-soap should be Kaō" (Fig. 6). Drawn like a radiant sunburst, the inner outline of the woman's head frames the copy as a brilliant idea, implying that in consultation with an array of "scientific" experts the Japanese woman was being enlightened about how to consume properly.

While the aestheticization of soap as a luxury commodity was critical to Nagase's early success in the cosmetics market, aesthetic strategies continued to be important even from the

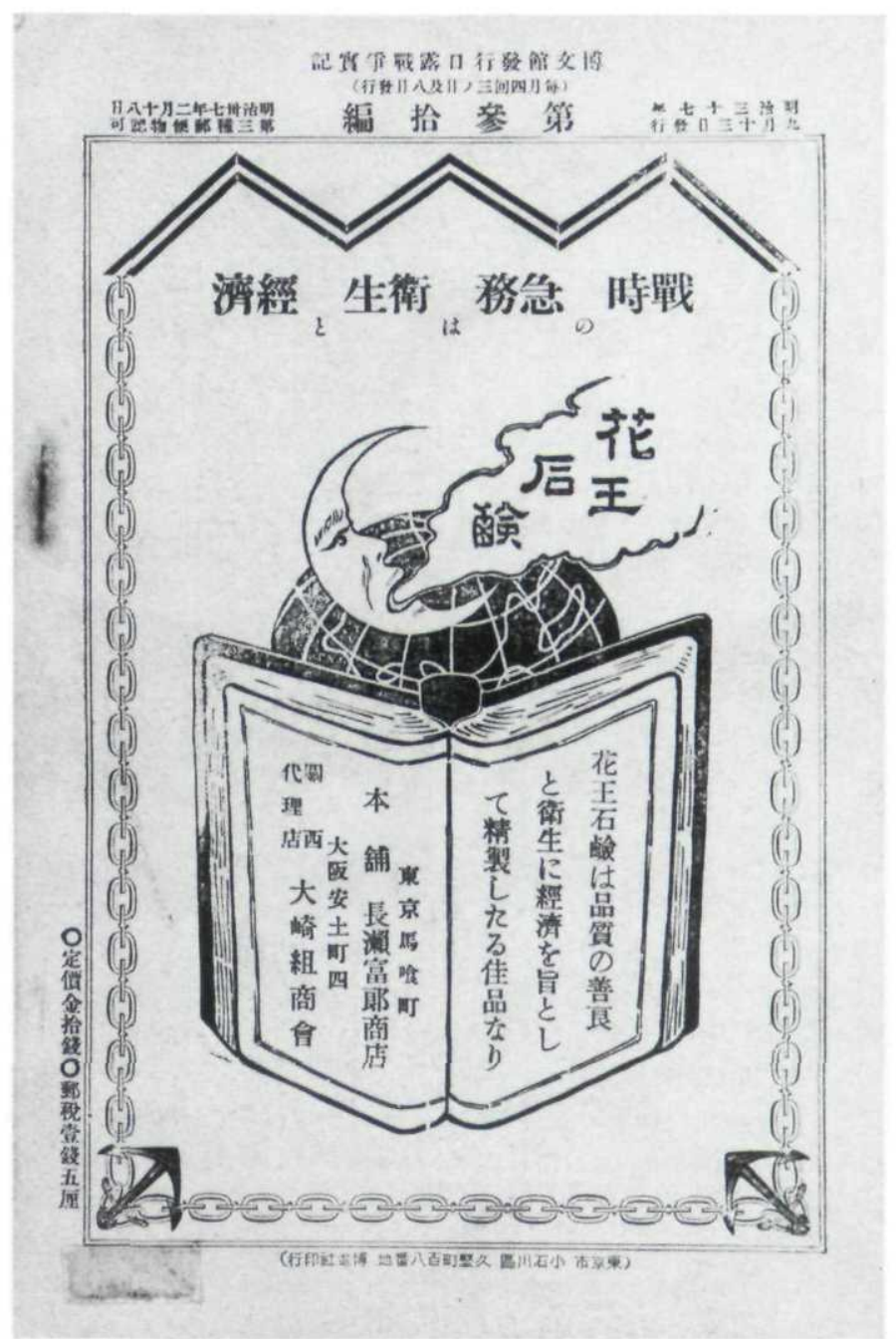

5 Kaō soap advertisement, back cover of the serial Nichiro sensō jikki [Actual Accounts of the Russo-Japanese War], no. 30, Sept. 1904. Tokyo, Kao Corporation

1920 s, when the state officially endorsed cosmetic soap as a staple good and removed it from the government's list of taxed "nonessentials," resulting in a marked increase in the personal daily use of soap products. ${ }^{21}$ After the Great Kantō Earthquake of 1923 devastated the area in and around Tokyo, the national capital, cosmetic soap gradually went from being a largely upper- or middle-class specialty consumption item to something used by average imperial subjects on a regular basis-in essence, cosmetic soap was being democratized. ${ }^{22}$ As business historian Louisa Rubinfien has noted, "What in 1920 had been considered novelties were by the late '20s gaining the status of 'necessities.' "23 Soap use was for every daily activity of the modern middle-class family: children returning from school, the family washing up before a meal, after a visit to the dusty library, after sports, before cooking, before and after a woman applied her cosmetics, after men rode the trains to and from work and when they left the office, activities graphically represented in a 1932 Kaō newspaper advertisement imitating the form of a tabloid-style journalistic photomontage. ${ }^{24}$

Ironically, Kaō's success in bringing its brand-name product to national recognition also encouraged a flood of new 
competitors, requiring the company to redouble its efforts in advertising and marketing. In 1911, close to two thousand soap manufacturers registered for trademarks. ${ }^{25}$ While leading the field, Kaō still competed with imported brand-name cosmetic products, such as Japan Lever Brothers' Velvet soap, whose advertisements featured a majestic seated female figure clad in a Greco-Roman-style flowing gown (the allegorical "Japania" perhaps). And Kaō went head-to-head with high-quality domestic products such as Mitsuwa soap, produced by Marumi-ya, and Shiseido soap. Both manufacturers relied heavily on decorative promotional graphics in the style of Art Nouveau (and later Art Deco) to conjure up luxurious images of elegant women and graceful floral motifs. Mitsuwa soap drew from the graphic sensibility of renowned Czech designer Alphonse Mucha, and Shiseido, whose broad array of cosmetic products extended from face tonics and creams to powders and perfumes, employed a delicate, linear style akin to that of Aubrey Beardsley, which featured willowy, fashionable young women with stylish coiffures in well-appointed modern interiors in combination with the company's delicate signature trademark, the camellia. ${ }^{26}$

Rampant unregulated and unauthorized price slashing in the mid-1920s combined with severe retail competition, however, caused additional problems for Kaō that sapped profits and eventually prompted radical rethinking of the company's business policies. When the second Nagase Tomirō took over as company president in 1927 , just two years after the company went from being a limited partnership to a corporation, he began a thorough overhaul of the company's production, management, promotion, and distribution strategies. This included a radical change in Kaō soap's marketing, from a high-class luxury item to a mass-market daily consumer good, which also meant cutting the price per unit by a third, to ten sen apiece.

\section{"New and Improved Kaō"}

In 1931 the company mounted a massive new advertising campaign for its lower-priced commodity, called "New and Improved Kaō" (Shinsō Kaō), which was overseen by the newly hired pioneering art director Ōta Hideshige (18921982), considered one of the first professional "art directors" in Japan. ${ }^{27}$ By the late 1920s, trade journal reviewers were already recommending Kaō shift its advertising approach, criticizing the company's designs, with their repeated use of similar soap bar and crescent moon imagery, as stiff and out-of-date. ${ }^{28}$ Since Ōta joined Kaō right at the time of a leadership change, under the new president he was able to exert tremendous influence in reshaping the company's image and advertising tactics at a crucial juncture.

The vast amount of innovative design produced for the New Kaō campaign and related subsequent campaigns into the 1930s constitutes the company's major contribution to the development of the commercial design field in Japan. That effort also exposes a fascinating connection between the democratization of soap and the instrumentalization of modernist styles, despite what one might presume to be the elitist connotations of these high-art aesthetics. Designers wielded a potent cultural weapon when they deployed modernist aesthetics in the mass media, as the new slick styles greatly expanded their expressive possibilities and the images they

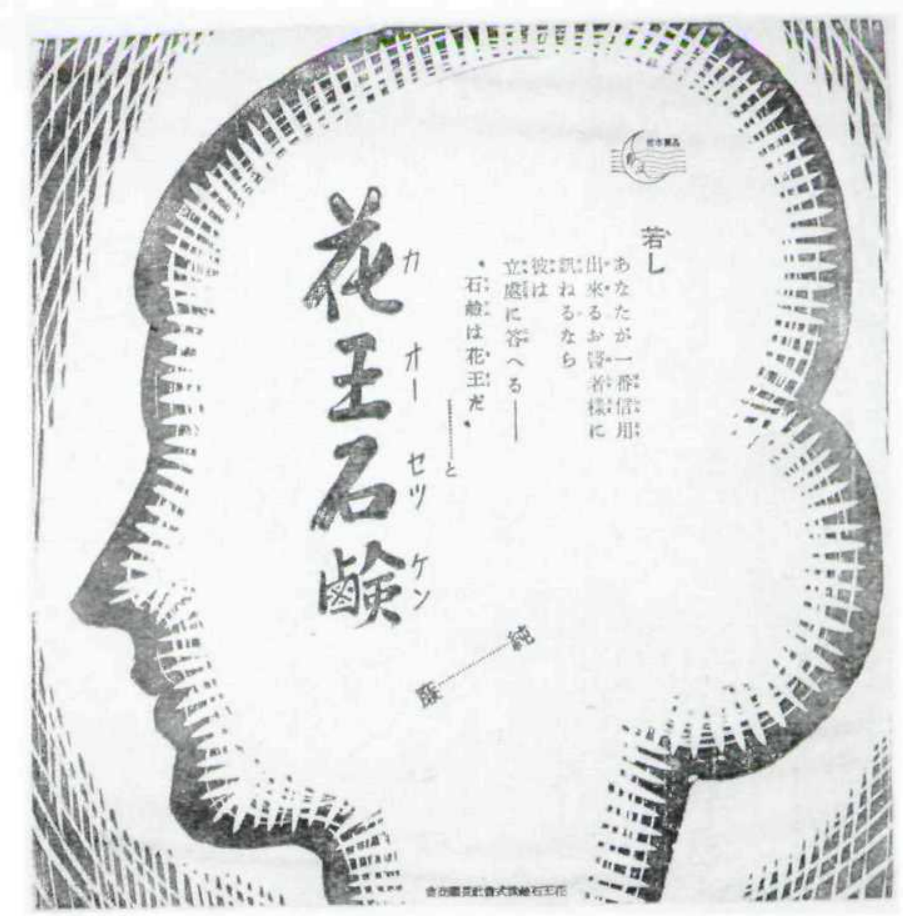

6 Kaō soap advertisement, from Tōkyō asahi shinbun, Mar. 9, 1930. Tokyo, Kao Corporation

created connoted innovation as well as ideologies of progressive civilization. One message this conveyed implicitly was that even through a commodity as mundane as a bar of soap, every man or woman could tap into an international culture of modernity. This was certainly the message the Japanese government communicated to its imperial subjects, so Kaō's modernist advertising reinforced official ideologies of hygiene praxis. ${ }^{29}$

After the company's reorganization, Ōta Hideshige was named the artistic director for Kaō's new design division within the advertising section, and he was personally responsible for selecting all the visual imagery as well as composing all the new copy for the "New and Improved Kaō" campaign. ${ }^{30}$ This included several overarching thematic copy phrases that appeared on series of advertisements, of which undoubtedly the most memorable is "From baby's first bath, Kaō." This simple, yet affecting phrase was a direct call to mothers to implement the new rituals of cleanliness at home to ensure the well-being of their children-the future of the nation. Ôta's other copy, however, included a number of statements that read more as exhortations to social revolution than as invitations to buy cosmetic soap: "A revolution in factory profits!" "A popular soap born of the masses!" "Listen to the vanguard of the reformation movement." This tied into Ōta's close personal identification with Christianity and left-wing politics. He was a member of the congregation and a protégé of the well-known Christian leader Ebina Danjō, who published the magazine Shinjin (New Man), an influential forum for the discussion of socialist humanism in the context of Christian faith. Two years after Ebina left Tokyo in 1920 to take up the presidency of Dōshisha University in Kyoto, he handpicked Ōta to replace him as editor-in-chief of Shinjin. More dedicated to left-wing politics than Christian humanist idealism, Ōta soon shifted the editorial focus of the 


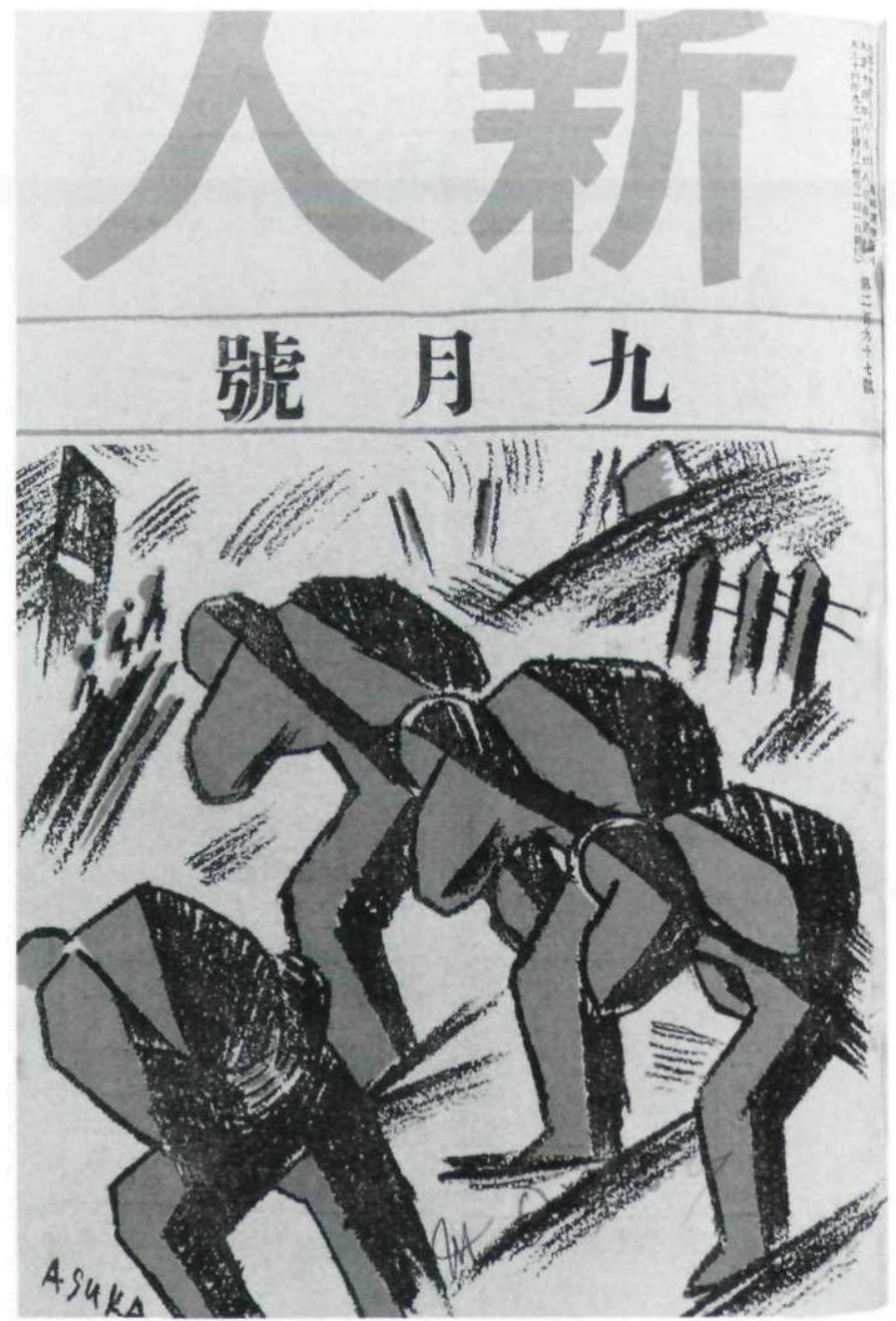

7 Asuka Tetsuo, cover design for Shinjin [New Man], no. 297 (Sept. 1925). Tokyo, Nihon Kindai Bungakukan

journal toward more radical Marxist political ideas, which greatly alarmed the rest of the church leadership. Continued friction with other pastors eventually led him to sever the journal's connection with the church. Loss of church sponsorship and readership, however, put the journal in dire financial straits, and the increased pressure of government censorship caused it to fold in $1926 .^{31}$

Still on close terms with his mentor, Ōta was introduced by Ebina to Nagase Tomirō II in Kyoto, when Nagase was a theology student at Dōshisha University, right before he would be called back to Tokyo to take up the reins of his father's company. The young Nagase also held strong leftist sympathies and was deeply influenced by Ōta. After Nagase hired Ōta at Kaō, the two began mobilizing the regular company workers, much to the dismay of the preexisting management, to reform the internal structure of the company to create "an ideal organization of production and sales" as part of the implementation of a larger social reformation movement. Such activism gradually alienated labor from management, with the president in this case uncharacteristically siding with labor. The company's attempts to democratize cosmetic soap by lowering the per-unit price stemmed partly from this philosophical shift, but the decision was also based on a practical need to stimulate consumption during the economic downturn of the Depression. ${ }^{32}$

Ōta quickly set about visualizing a new image of Kaō soap for the consumer market. To augment his staff, in April 1930 he hired two graduates of the design division of the prestigious Tokyo School of Fine Arts (Tōkyō Bijutsu Gakkō)Asuka Tetsuo (also known as Takahashi Tetsuo, 1895-1997) and Okuda Masanori (1901-1967) — to execute his programs in-house. ${ }^{33}$ A skilled oil painter who had studied under the renowned Japanese academician Okada Saburōsuke, Asuka, like many artists of his generation who trained with conservative painting masters, took his work more in the direction of the new expressionistic styles of Post-Impressionism. ${ }^{34}$ Just one year after Asuka graduated in 1919, his painting was selected for exhibition at the prestigious annual juried exhibition of the Nika-kai (the Association of the Second Section), a modernist offshoot of the Ministry of Education's official academic art salon. And in 1925, at Ōta's request, he designed covers for several issues of Shinjin, for which he produced dynamic, abstracted figurative sketches of workers and factory scenes that resonated with the leftist orientation of the journal (Fig. 7), a style and content that he then brought to Kaō advertising. His approach quickly won praise from advertising critics who saw the "fresh" new designs as expressing the "strong new mood" of the company's transformation (Fig. 8). ${ }^{35}$

Graduating in 1925, several years after Asuka, Okuda submitted as his final painting project a composition of intersecting geometric forms and simply delineated figurative shapes that reflected the continued popularity of abstracted Post-Impressionist painting styles. ${ }^{36} \mathrm{He}$ was soon hired as a packaging designer for the Morinaga confectionery company, also a corporate pioneer in innovative promotional strategies, which was similarly employing a range of modernist artistic techniques in its advertising. ${ }^{37} \mathrm{He}$ and Asuka had previously collaborated with the Barrack Decoration Company (Barakku Sōshokusha), active from late 1923 until mid1924, a group organized by designer and ethnologist Kon Wajirō, their senior schoolmate, whose mandate was to decorate the interiors and exteriors of temporary residential and commercial structures known as "barracks" that were erected in the wake of the devastation of the Great Kantō Earthquake. The Decoration Company members considered these lowcost, ephemeral buildings that arose directly out of the exigencies of the disaster as a new, socially significant architectural form and viewed their decoration activity as a means of shaping perceptions of the regenerating urban environment. The structures also served as monumental public canvases for free-form artistic expression. ${ }^{38}$

Young artists like Asuka and Okuda quickly learned about the newest cultural and artistic trends abroad from the many Japanese artists traveling between Japan and the West (including the Soviet Union). They either had direct contact with these artists through professional societies or read the accounts often published in art journals. ${ }^{39}$ Moreover, a host of international and domestic design trade publications provided regular access to the latest developments in world design, constituting a transcultural and transnational traffic of images circulating on a media highway that flowed in all directions around the globe ${ }^{40}$ From the 1920 s, most major 
8 Asuka Tetsuo, designer, Kaō soap advertisement, from Tōkyō asahi shinbun, Mar. 8, 1931 (photo: National Diet Library)

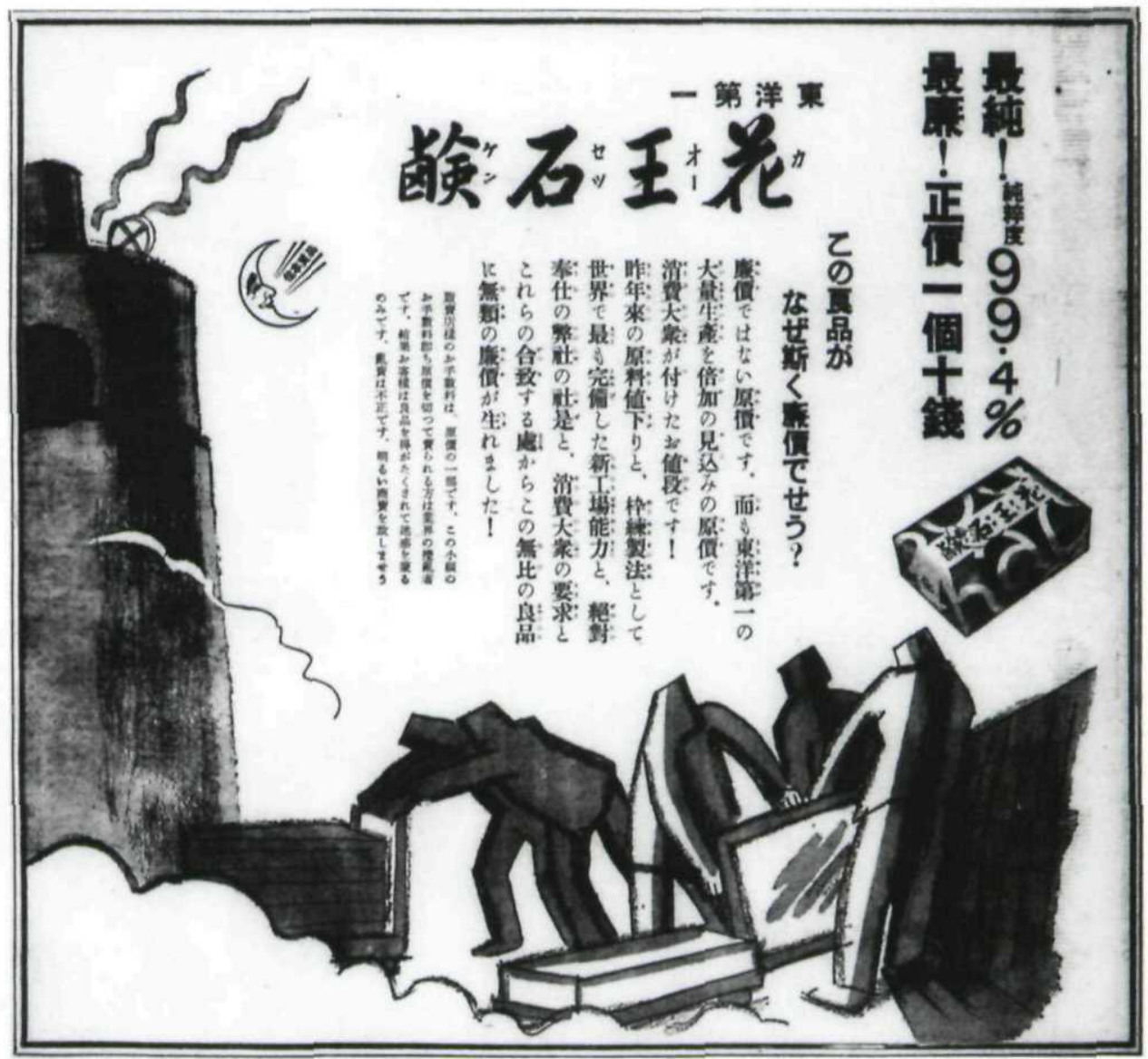

Western design trade publications were known in the Japanese commercial art community, and the information they presented played a critical role in the instrumentalization of modernist styles. ${ }^{41}$ In an age of lax or nonexistent copyright laws, Japanese publishers reissued foreign images with impunity, providing a rich encyclopedia of styles and mediums for local reference and adaptation. Many of the copious journal illustrations were accompanied by translated excerpts from original publications and/or editorial comments by Japanese theorists.

The advertising design trade journal Kōkokukai (Advertising World), for example, was one of the most important agents in mediating this kind of information, frequently excerpting material from the German design journal Gebrauchsgrafik, the French Publicité, and the British publications Commercial Art and Modern Publicity. But Kōkokukai was certainly not alone. It had the company of Shōgyō bijutsu (Commercial Art), Kōkoku to chinretsu (Advertising and Display), Teikoku kōgei (Imperial Crafts), and Insatsu to kōkoku (Printing and Advertising). That is not to mention the proliferation of professional and amateur photography journals that also circulated key information on commercial photography or applications of art photography in the commercial sphere. Trade journals served as important supplements to school training, as they published practical, how-to information on state-of-the-art techniques concerning design layout and color theory, as well as reports on current trends in media and advertising research. When considered in combination with the multitude of published design compendiums that collated and systematized design information for producers and retailers, it becomes clear how these publications nurtured the burgeoning new professional field of commercial art and sustained a lively discourse on design. ${ }^{42}$

The "New and Improved Kaō" campaign included everything from entirely revamping the product's packaging to initiating direct marketing nationwide. The shift to direct marketing, as opposed to the use of middlemen distributors, was very significant from an advertising standpoint because it meant relying even more on consumer recognition of product brand-names and manufacturer identity.

The first step in this direction was a major facelift for the Kaō soap bar. In 1930 the company sponsored an invitational competition for a new package design and, as a result, switched to a radically different red-colored packaging. Eight individual artist-designers submitted a total of twenty-eight separate design concepts. The diverse artistic approaches ranged from the logo-oriented, repetitive patterns suggested by the prominent commercial designer Sugiura Hisui, head of the design division at Mitsukoshi department store, who worked in the Art Nouveau style, to the more typographic and abstract designs of self-proclaimed avant-garde artists like Yoshida Kenkichi and Murayama Tomoyoshi (Fig. 9). Others who submitted designs included well-established applied arts and textile designer Hirokawa Matsugorō, who was a regular exhibitor in the crafts division of the annual imperial art salon. The competition attracted such talent because Kaō paid one hundred yen for an individual's entries and an additional three hundred yen for the winning design. The combined amount of four hundred yen constituted a considerable portion of a year's income for most people in the design field. ${ }^{43}$ 

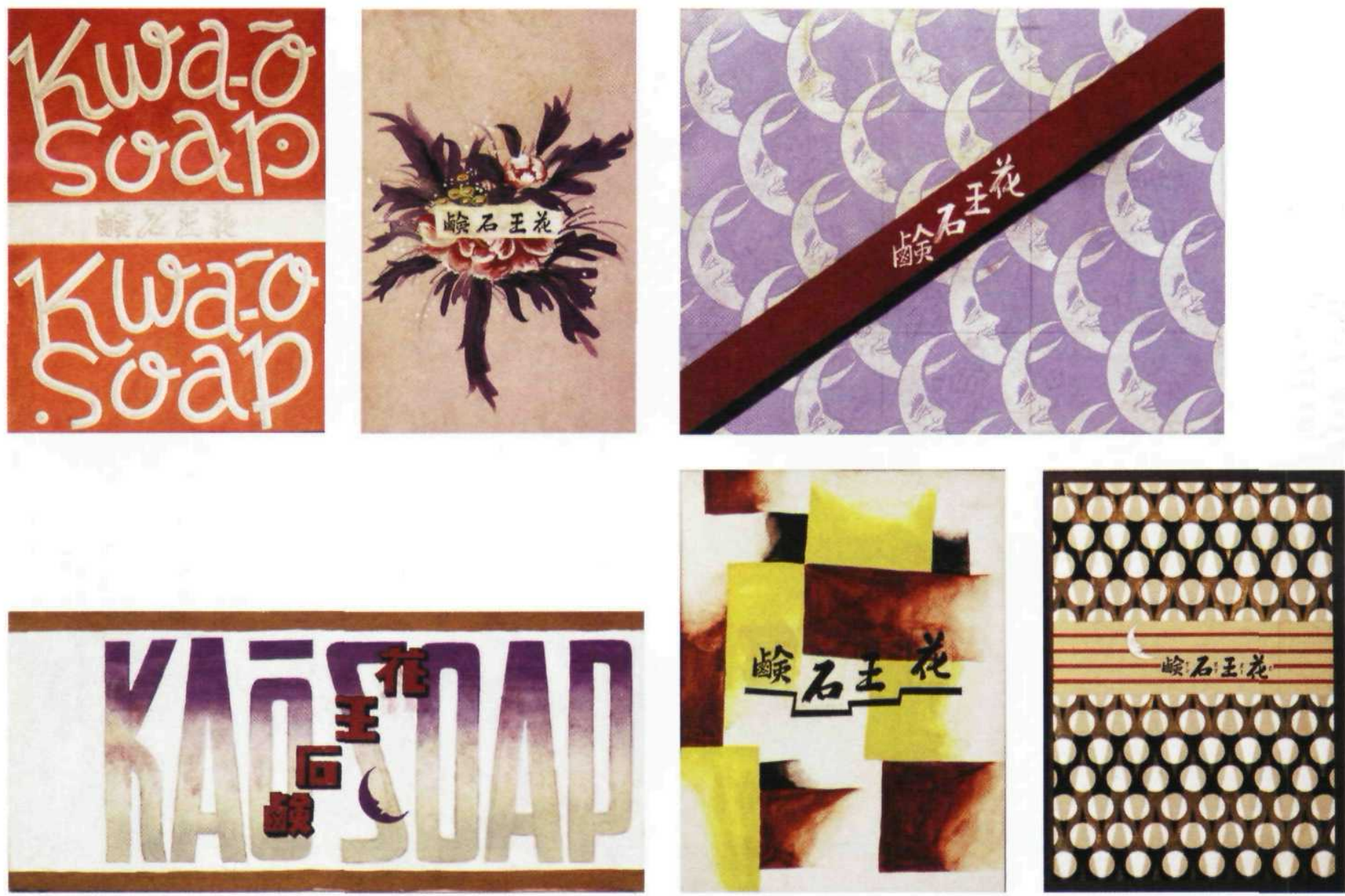

9 Original drawings for the "New and Improved Kaō" soap package design competition, above, from left: Hara Hiromu (winning entry), Hirokawa Matsugorō, Sugiura Hisui; below, from left: Yoshida Kenkichi, Murayama Tomoyoshi, and Okuda Masanori. Tokyo, Kao Corporation

Öta recommended to the planning division and production conference the unknown Hara Hiromu's (1903-1986) bold, modern red package design, launching an illustrious career that established Hara as one of the most important and powerful graphic designers in Japan until his death in 1986. ${ }^{44}$ Hara studied at the Tokyo Metropolitan Craft School (Tokyo Furitsu Kōgei Gakkō) under Miyashita Takao, one of the first teachers to specialize in the field of "graphic design" (insatsu zuan, also translated as printing design). It was, in fact, Miyashita who had been invited to submit to the Kaō competition, but he was unavailable and recommended that his student, who had graduated in 1921 and was now heading the printing program, take his place. ${ }^{45}$

Although Hara was not yet well known for his design projects, he was familiar to many as a translator and author of essays on graphic art, particularly typography. He was responsible for translating the important European text Die neue Typographie (The New Typography) by Jan Tschichold from German into Japanese in 1928. Hara was drawn to the powerful cinematic montage aesthetics of famed Russian director Sergei Eisenstein and revolutionary designers Rodchenko and Lissitzky. He later employed these in his highly acclaimed photomurals promoting Japanese tourism, which were installed in the prize-winning Sakakura Junzō Japanese Pavilion at the Paris 1937 International Exposition and in the pages of the Japanese wartime propaganda journal Front.
Hara's design on a vermilion background became emblematic of the new company image, so much so that designers commonly referred to the red as the "Kao color." He also supplemented the calligraphy-style characters used for the company's name by surrounding them with stylish Western typography spelling out "Kwaō." The w in the older style of transliteration was removed when the package actually went into production (Fig. 10). ${ }^{46}$ The new design and its vibrant color greatly simplified, while intensifying, the visual impact of the product. It also effected a radical reduction in text on the packaging. The loopy letterforms in Hara's typography rolled off the corners of the soap bar, just legible enough so that "soap" and the brand-name "Kaō" could be discerned. Near the subtly outlined form of the crescent moon logo sat the only other text, "quality standard."

The redesigned Kaō soap bar figured prominently in all subsequent promotional campaigns, and the red stood out in the otherwise predominantly monochromatic settings of prewar publications. The same Kaō red and Hara's distinctive typography were selectively applied across the company's spectrum of soap-related product packages, including canned shaving powder and boxes of medicinal soap. Hara's newly designed brand image was also quickly integrated into Kaō's retail-oriented promotional materials, such as storefront signboards, which the company produced and distributed to local retailers. 
The image was then emblazoned across Kaō-brand promotional materials, and these, presented to distributors and retailers, served as small token gifts of gratitude for their loyal collaboration with the manufacturer. Many of these gifts were intended as decorative publicity items to adorn shop interiors. One of them, the Kaō calendar (Fig. 11), in 1932 cleverly used the eye-catching red bar of soap to serve as the calendar itself. The soap bar opens to reveal a monthly schedule with pithy exhortations to buy Kaō products on each page.

New Kaō began sales in 1931. During the 1920s, around 3 percent of Kaō's annual budget had been spent on advertising, but after the launch of New Kaō this amount leaped up to 16 percent and remained between 15 and 18 percent thereafter. ${ }^{47}$ In 1922, over 160 million lines of advertising were sold in Japan (cosmetics, food products, medicines, and publications were the leading advertisers). Kaō was consistently ranked in the top fifteen companies purchasing advertising space.$^{48}$ Like the Nagases, Ota believed fervently in the efficacy of newspaper advertising and devoted considerable resources to this medium. The full-page newspaper advertisement that kicked off the "New and Improved Kaō" campaign, which ran in all the major Japanese newspapers, featured a striking photographic image shot from overhead by commercial photographer Kanamaru Shigene (1900-1977), director of the small commercial photography studio Kinreisha (Fig. 12) ${ }^{49}$ This was, incidentally, one of the earliest examples of a full-page photographic newspaper advertisement in Japan.

Kanamaru's photograph shows a crowd of company employees standing outside the production factory holding up banners and energetically raising their hands in triumph. The copy, reminiscent of Proctor and Gamble's endorsement for Ivory soap, reads, "Today is the day of New and Improved Kaō, $99.4 \%$ pure, net price 10 sen apiece. ${ }^{n 50}$ Bleeding off the edges of the image, the sea of Kaō workers seems to go on indefinitely - a flood of cheerful labor, male and female, interspersed with a convoy of Kaō soap trucks ready to charge out into the streets. The image responded to Kaō president Nagase Tomirō II's rallying cry, printed in the new company

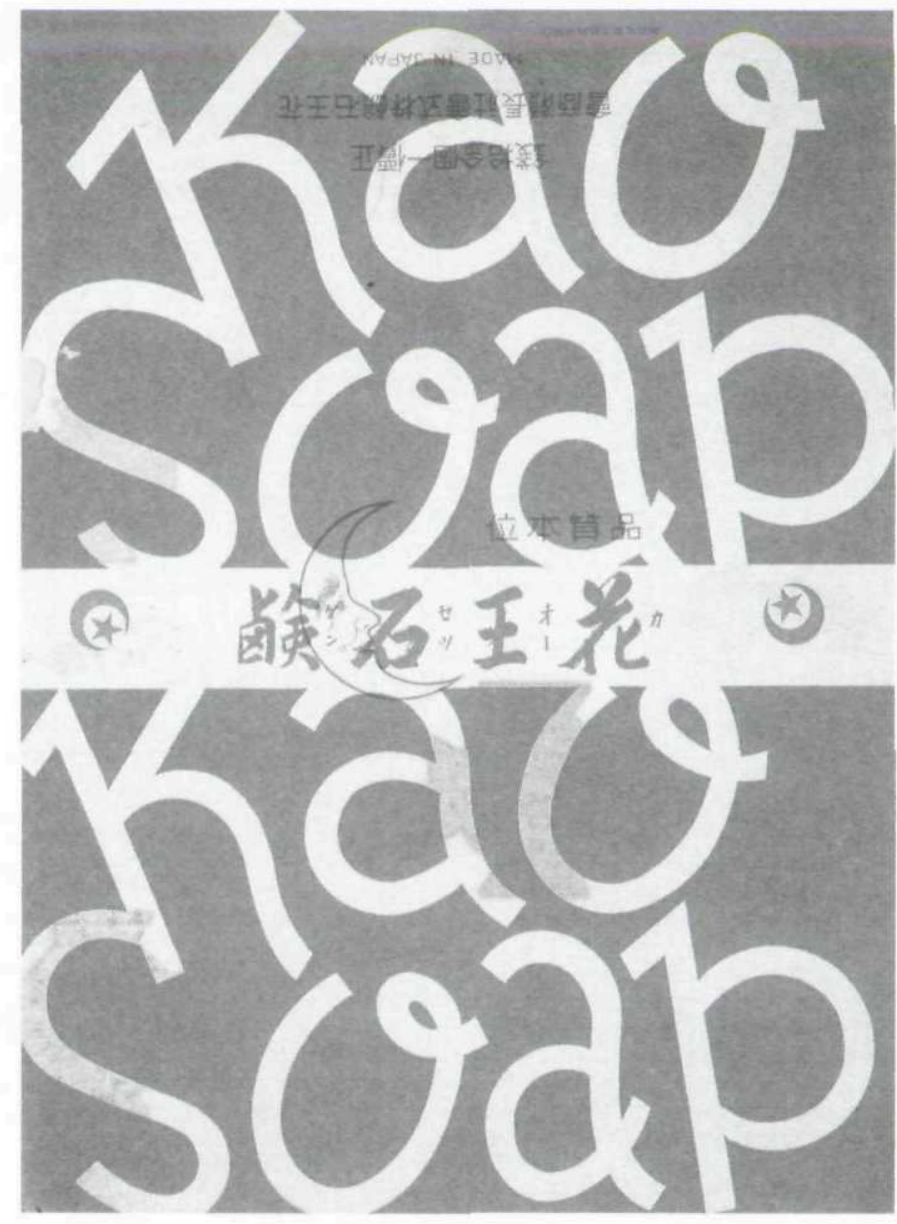

10 Hara Hiromu, designer, New Kaō packaging paper, ca. 1930. Tokyo, Kao Corporation

house organ Nagaseman, in which he enjoined all employees to behave like soldiers in the company fight on the battlefield of the consumer market. ${ }^{51}$

Kanamaru's photograph also clearly drew from triumphal images of industry and social revolution emanating from the
11 Kaō soap promotional calendar for 1932, open and closed. Tokyo, Kao Corporation
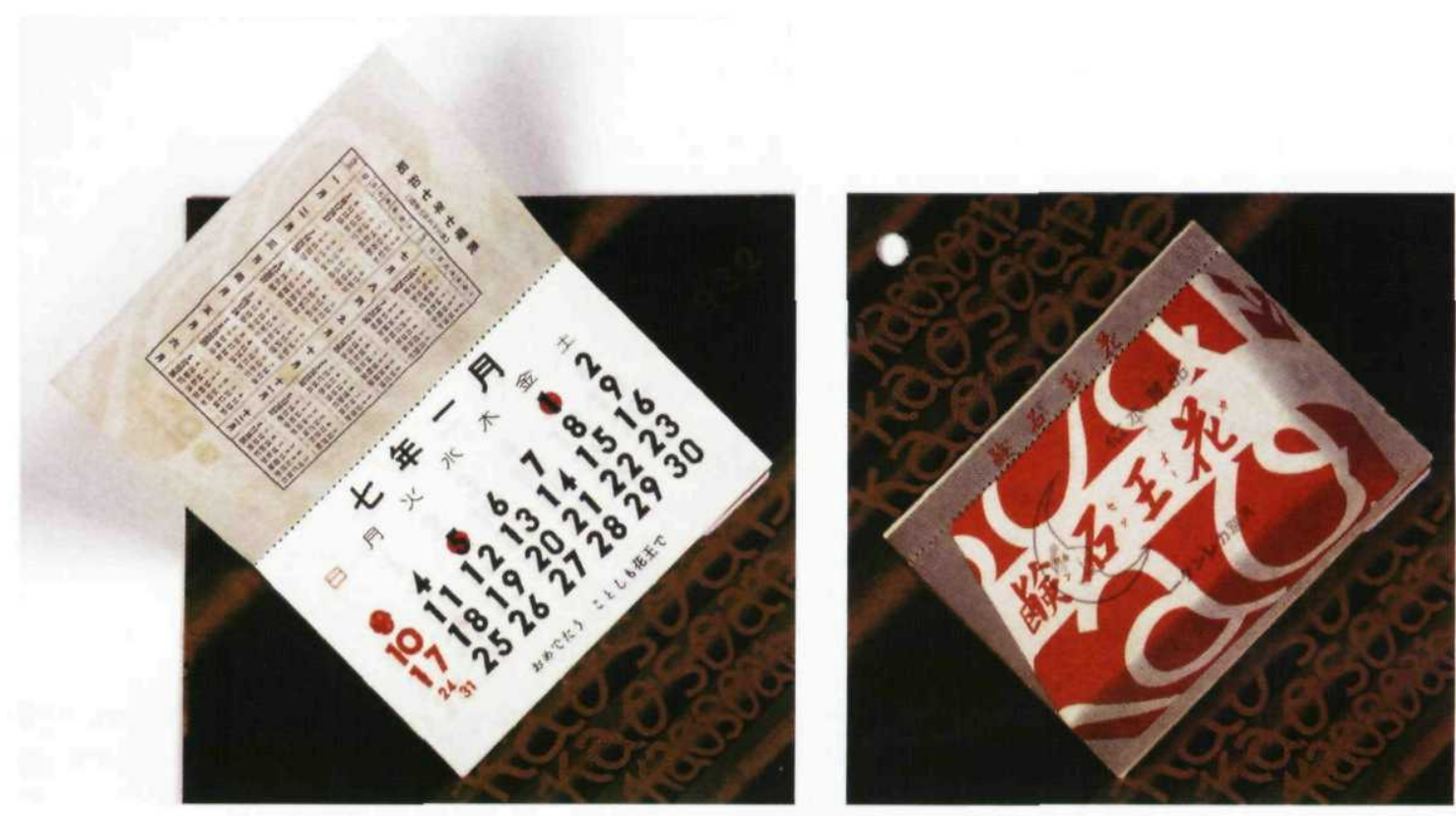


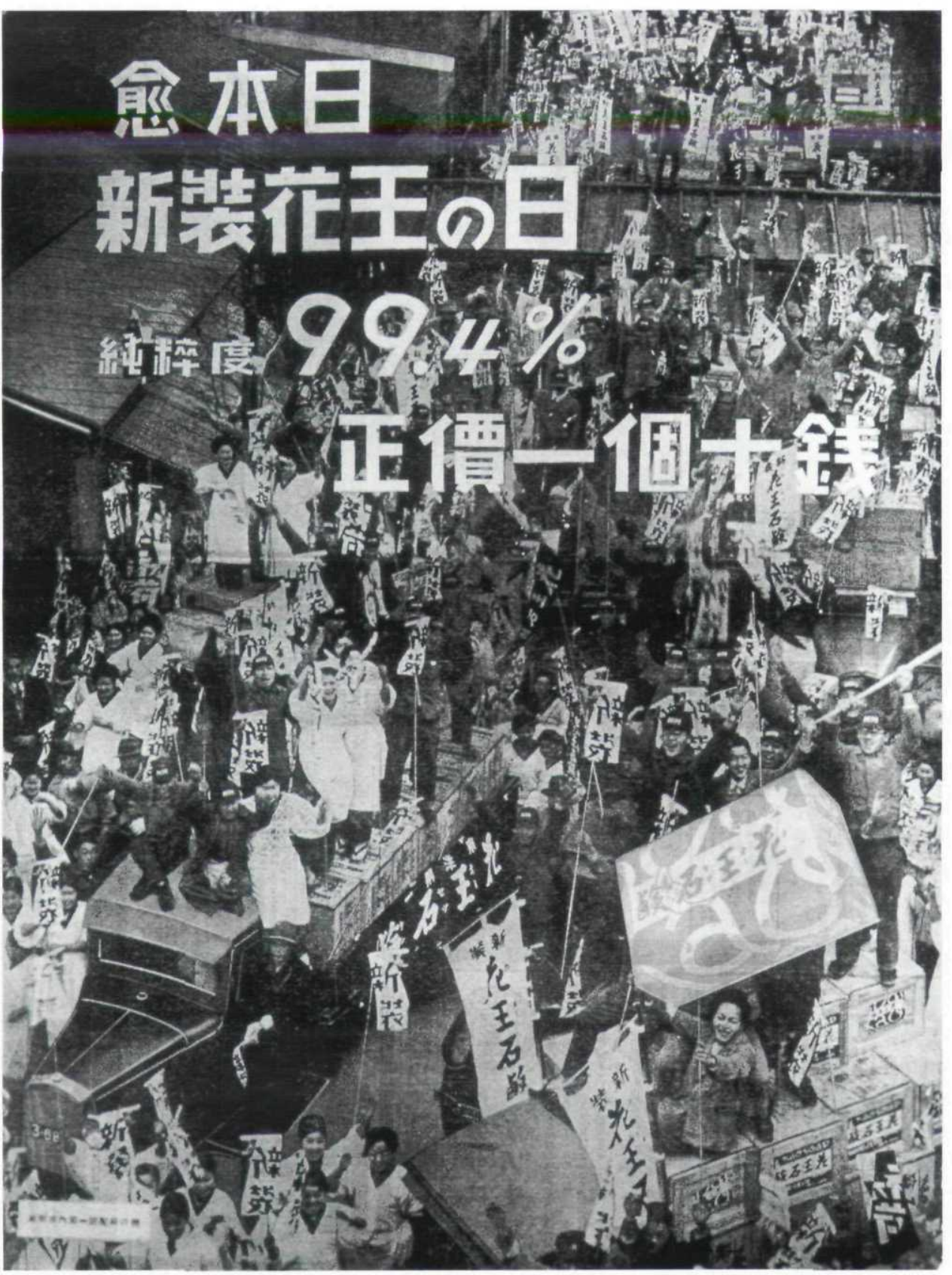

12 Kanamaru Shigene, photographer, Kaō soap advertisement launching the "New and Improved Kaō" campaign (Shinsō Kaō), run in all major Japanese newspapers, Mar. 1931. Tokyo, Kao Corporation
Soviet Union in widely circulated propaganda journals such as the USSR in Construction, designed by Rodchenko and Lissitzky. ${ }^{52}$ At first glance, this might seem an odd choice of inspiration for depicting production under a capitalist system. Yet it is less strange if one remembers that in 1918, Lenin, known to have a photograph of the great scientific manager American industrialist Henry Ford over his desk, stated, "The possibility of building socialism depends exactly on our success in combining the Soviet power and the Soviet organization of administration with the up-to-date achievements of capitalism. We must organize in Russia the study and teaching of the Taylor system and systematically try it out and adapt it to our ends." 53 And as hard as Soviet designers tried to distance themselves from embourgeoisement, according to Leah Dickerman, in the context of the Soviet Union's New Economic Policy implemented in the early 1920 s, it was increasingly difficult to distinguish "Soviet labor from the alienated labor of capitalism, the revolutionary commodity from the commodity fetish, and Soviet technology from the oppressive machines of the industrial revolution." 54

Many Japanese manufacturers positioned themselves as progressive producers in terms of their technologized, precision manufacturing and their high-quality products, which were marketed as bringing a healthy new life to the Japanese collective in line with state objectives. Thus, in Kaō's case, this conflation of labor and capital in a burst of revolutionary victory presents the company at the core of the imagined community of the nation, surrounded by concentric rings of enthusiastic consumer subjects.

Moreover, like the modern housewife-mother, the modern industrial laborer represented a critical building block of the nation. Both worked in spheres where concern for health and hygiene was paramount. This opened up a potentially prof- 
itable marketing sector for Kaō soap products. As representatives of the rapidly proliferating new forms of industrial capital, Kaō and other modern manufacturers were engaging increasing numbers of factory workers to produce their products. Therefore, company publicity material deployed aestheticized images of happy, clean, and productive industrial labor-male and female-both as a testament to its cuttingedge production standards and as an invitation to labor itself to participate in these new hygiene practices through its "close friend" Kaō soap, thus effectively conflating the producer and the consumer. ${ }^{55}$ The focus on industrial labor was part of Kaō's bid to further democratize soap use, and the full-scale application of modernist pictorial strategies was keyed to this process of democratization, although this attempt initially met with less success than anticipated.

In one advertisement for the popular science magazine Kagaku chishiki (Science Information) from October 1930, a simplified figure in overalls rendered in a painterly PostImpressionist style is shown casually leaning against a smokestack that emits puffs of smoke (Fig. 13). Next to the figure reads the brief copy: "quality, purity, value, and health." This leisurely image of the worker seems to imply that Kaō's modern production offers labor the luxury of some relaxation, a desirable notion for anyone toiling in the factories, although fundamentally misleading.

Akin to the "modern aestheticists of industry" Charles Sheeler and Margaret Bourke-White, Kaō designers employed glorified images of stalwart workers and gleaming factory complexes in publications issued in the Japanese metropole and its colonies such as Korea. ${ }^{56}$ One brightly colored advertising image that ran in Betsu kenkon (Another Universe), a little-known literary journal with proletarian leanings published in Korea, shows a square-shouldered worker, confidently looking to his side as he surveys a vast industrial complex (Fig. 14). The copy text, provided in a mixture of characters and Korean Hangul, reads,

Best Wishes in the New Year, 1931!

This year we are even more determined that Kaō

(Hwawang) soap, renowned for its good quality and low price, be embraced by commoners/the masses. A thoroughly good product resulting from forty years of research, at an absolutely low price due to the mobilization of Asia's best production facilities.

Please don't change. Use our product regularly. ${ }^{57}$

While unlike the profoundly racialized images in British imperialist soap advertising Anne McClintock has identified, the Kaō image similarly alludes to the politics of empire building through imperialist expansionism on the Asian peninsula and continent. ${ }^{58}$ It annexes what is presumably Korean labor, or elides the difference between Japanese and Korean labor, superimposing Japanese hygiene practices onto the colony as part of the colonial civilizing mission. A standard Kaō message calls out to the viewer above the product brand-name, "Number One in the Orient"- a position the Japanese Empire was also increasingly claiming for itself.

Despite the masculine identity of the industrial sphere, there was actually a sizable and growing population of female factory workers. These workers were, in fact, a regular topic

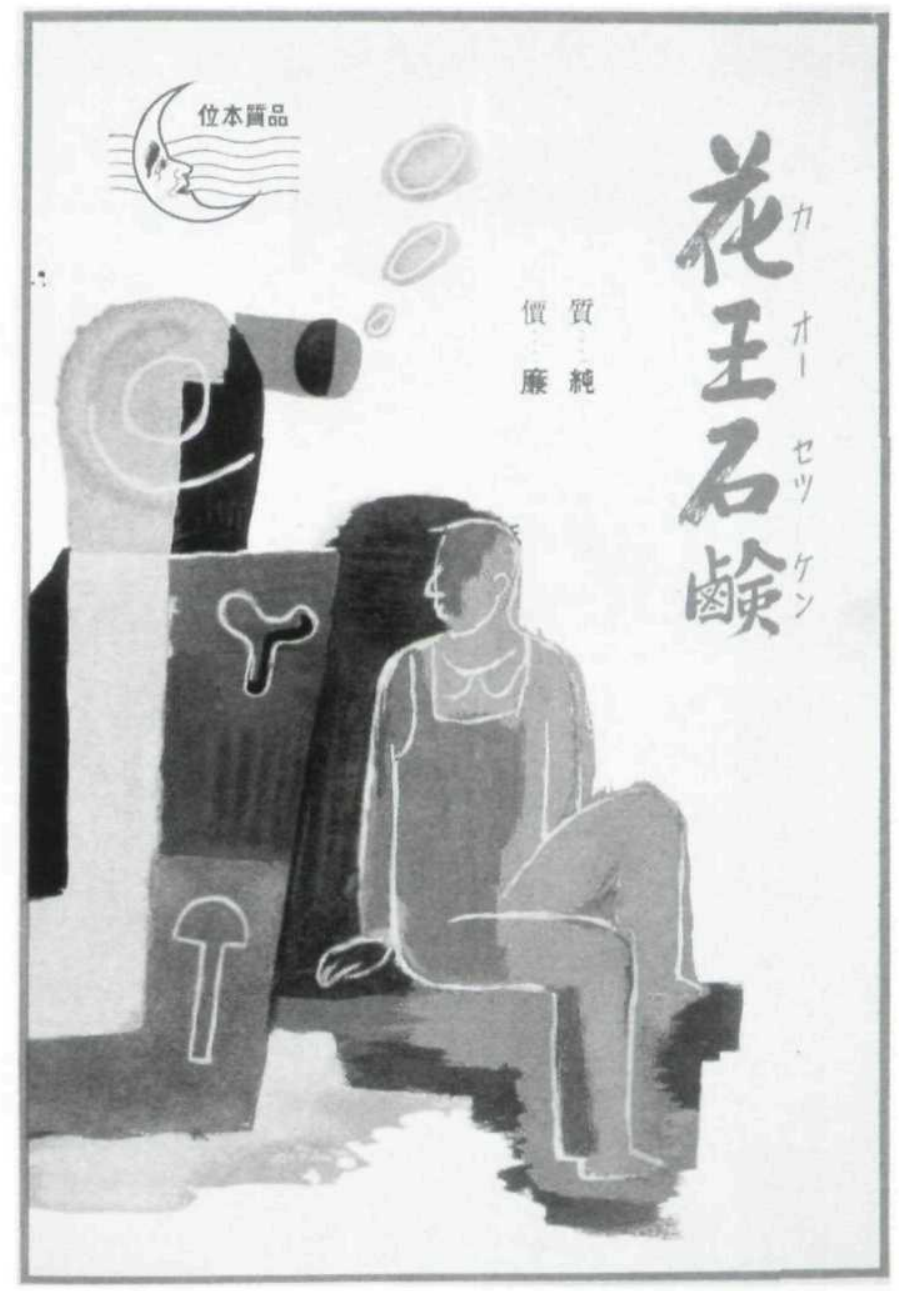

13 Kaō soap advertisement, from Kagaku chishiki [Science Information], Oct. 1930. Tokyo, Kao Corporation

of impassioned discussion among Japanese social reformers, who were attempting to refashion the worker into an idealized image of "the Japanese woman." They envisioned this reformed female factory worker as a buttress to the nation and a critical $\operatorname{cog}$ for maintaining Japan's capitalist expan$\operatorname{sion}^{59}$ Kaō's substantial female labor force frequently appeared in company advertisements and promotional material in the 1930s.

"Double-time production day and night!" is preparing for "the approaching day of New and Improved Kaō's arrival," read one advertisement that ran in the Yomiuri shinbun just a month before the product's launch (Fig. 15). "Precisely because we have confidence in the product's quality, we are taking this profitless risk with this fine product at this price; We will actually prove the rationality of this revolutionary profitability by attracting the support of the consuming masses!" exclaimed additional copy, placed above the heads of rows and rows of apron-clad female workers with their heads bowed intently on work, their image expanding across the page in a seemingly endless assembly line. Shooting vertically out of this mass of women is a surging arrow that encompasses the machinery of mass production, appearing as if it is actually producing the women as well. The arrow simultaneously reads as a visual emphasis of the product's 


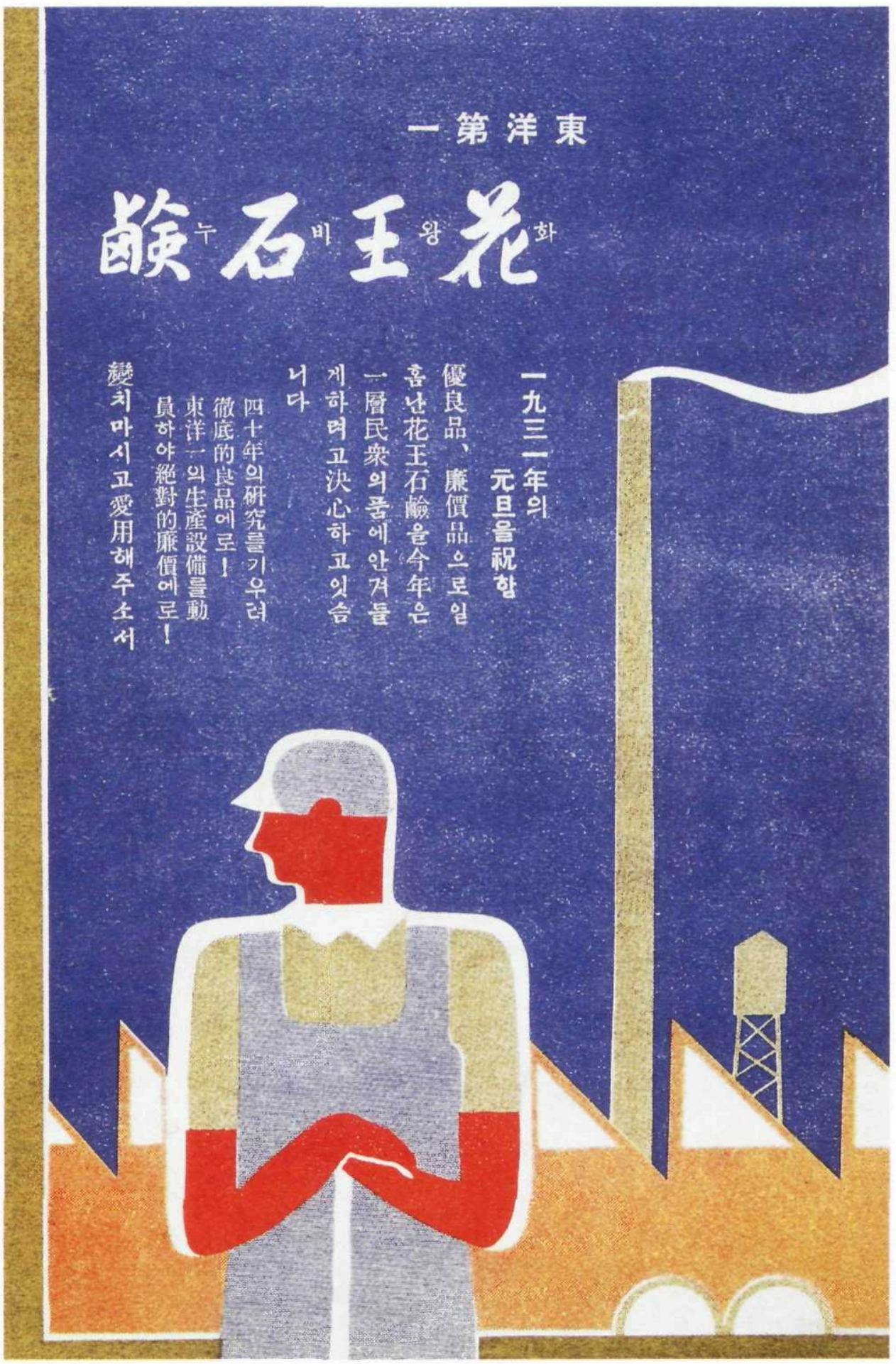

14 Kaō soap advertisement, from Betsu kenkon [Another Universe], Jan. 1931. Tokyo, Kao Corporation elevated purity asserted to the left. As company workers (but also as women and mothers), by association the female employees attest to the product's quality.

Later in the decade, in 1939, a cover for the internal company publication Kā̄ buretin (Kā̄ Bulletin) shows a montage of photographs stylistically reminiscent of the work of Bauhaus designer Herbert Bayer, in which an image of a small child holding up his/her hands for inspection is superimposed on a bustling image of Kaō female factory workers packaging soap bars (Fig. 16). Above the child's head, the text reads, "Easy disinfection, handy soap" (tegaru na shōdoku, tejikana sekken). The text and visual design revolve around the image of hands (te) - the site of contamination and disinfection. Hands are the visual centerpiece of the composition, they are the instrument of the women's labor, and the character for hand appears in both of the Japanese copy words "easy" and "handy," which is highlighted by having the rest of each word written out phonetically in script. ${ }^{60}$ The expansion of Kaō marketing to the working class, including invocations to its own employees, continued to identify women as the primary agents of family hygiene. Here women policed their family's cleanliness and were themselves policed by rings of authority, starting with their employers and extending to the state. At the same time, as diligent Kaō em- 
15 Kaô soap advertisement, from Yomiuri shinbun, Feb. 26, 1931. Tokyo, Kao Corporation

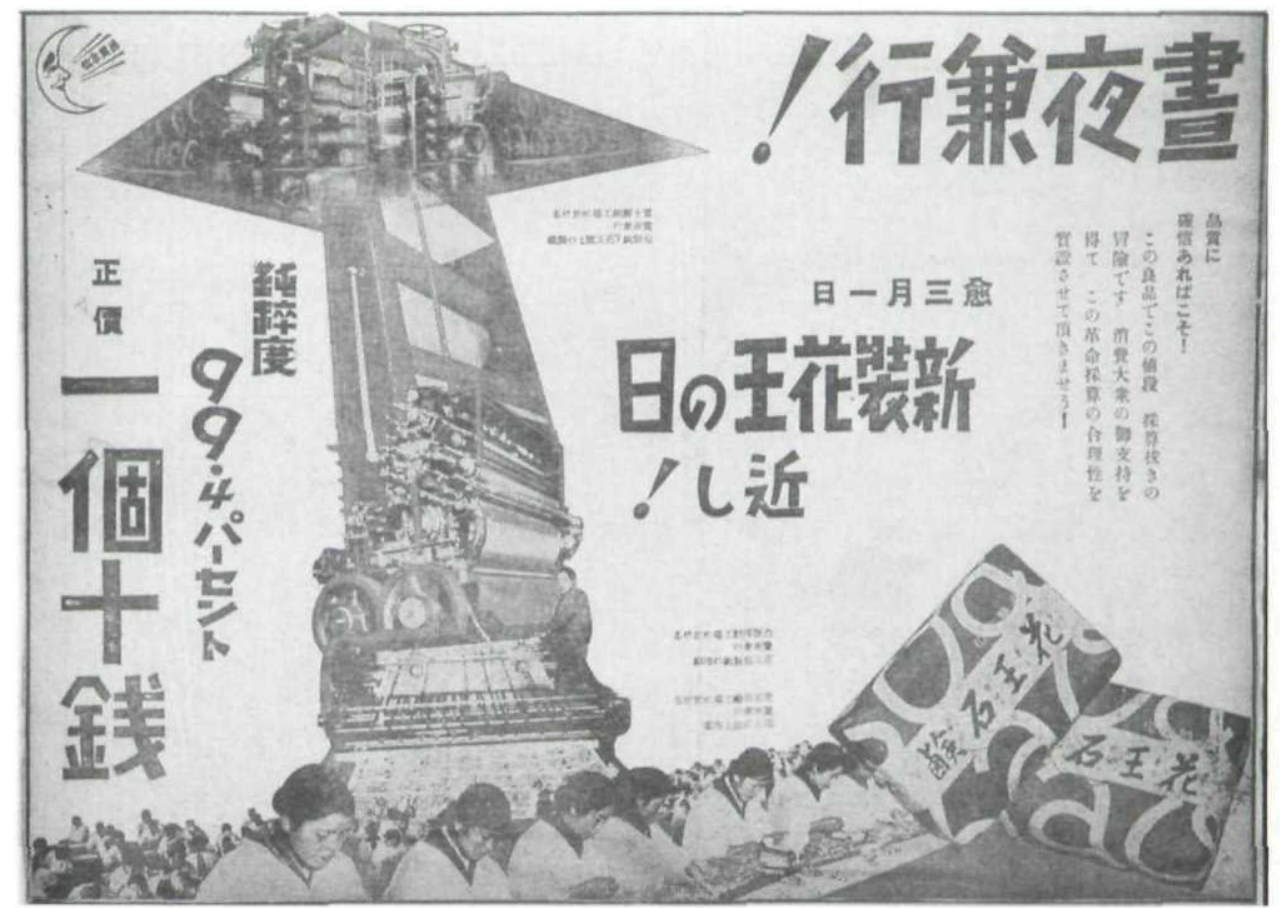

ployees, they were responsible for the collective future health of the nation, as symbolized by the child.

In the "New and Improved Kaō" campaign, even salespeople were cloaked in the new Kaō wrapping. The company hired "mannequin girls" to stand at all major department stores throughout the Kantō region holding balloons to promote the campaign (Fig. 17) ${ }^{61}$ On several occasions wellknown popular film actresses, such as Hosokawa Chikako, were enlisted to greet consumers at point-of-purchase displays and in front of stores (Fig. 18). Hosokawa and the other mannequin girls wore logo-patterned yukata (cotton summer kimono) and head scarves that prominently displayed the new Kaō typography dynamically rippling across their bodies. ${ }^{62}$ Just as Paris-based artist Sonia Delaunay had mapped a vibrant and sensuous abstract geometry onto the bodies of models adorned in her "Simultaneous clothing" that transformed them into "luxurious and ornamented surface[s]" at the 1925 Paris International Exhibition of Modern Decorative and Industrial Arts, so, too, did the Kaō-logo garb exploit the curves and movement of the female body to animate the decorative patterning of the costume. ${ }^{63}$ This suited the fashionable context of the upscale department store. But the superimposition of an apron on top of the logo costume, one of the classic prewar Japanese ciphers of female labor (domestic and industrial), mitigates against the sensuality of the mannequin's body, countering it with a desexualized (procreative or productive) image of woman as wife, mother, and worker. Here the contradictory identities of women and cosmetic soap are revealed to be intertwined-woman as sexualized consumer, woman as rationalized consumer; soap as luxury commodity, soap as hygienic necessity.

French critics interpreted Delaunay's draped models as implying a fundamental need for the surface modification of women's bodies in the quest for aesthetic beauty. ${ }^{64}$ In the Japanese context, the adornment of the Kao garb implied a similar call for surface modification-however, in this case,

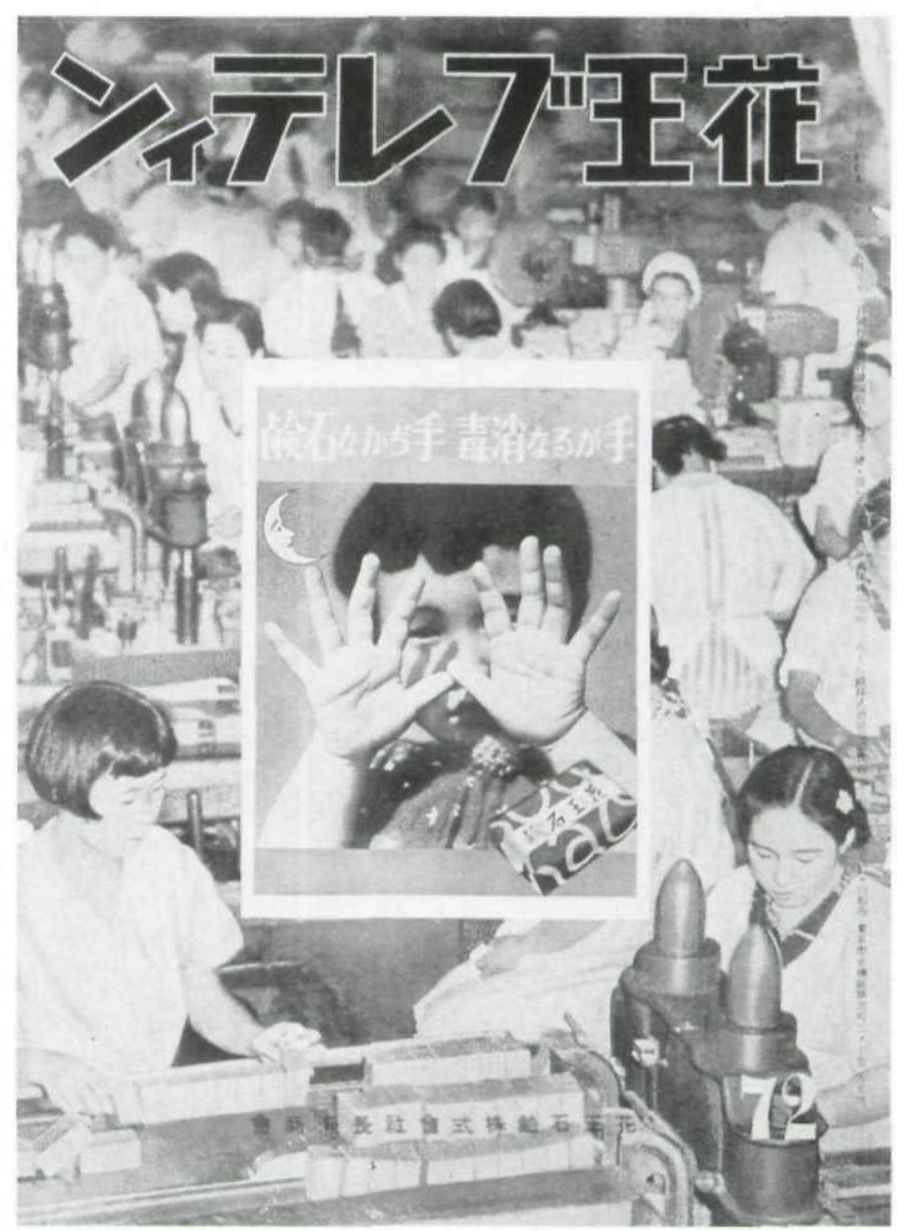

16 Kaō buretin [Kaō Bulletin], no. 72 (Aug. 1939). Tokyo, Kao Corporation

not just the transforming maquillage of la toilette, but the hygienic reformation brought about by cleansing the body. On-site advertising banners pictured in extant photographs of these events indicate that they were often launched in 


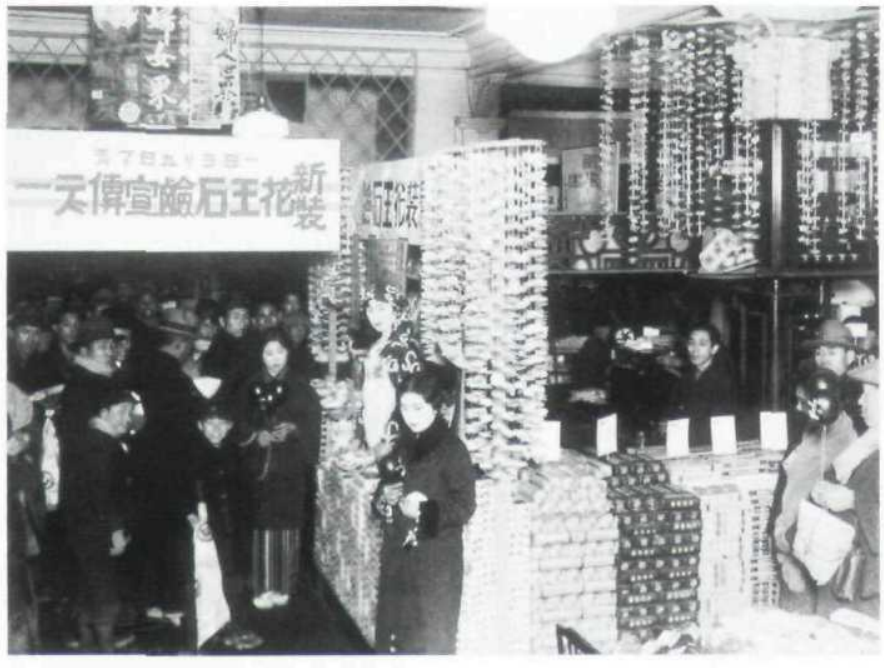

17 New Kaō soap promotional event in a department store in the Kantō region (probably Matsuzakaya), ca. 1931. Tokyo, Kao Corporation

collaboration with women's magazines like Fujin sekai (Women's World), Fujōkai (Women's Sphere), and Shufu no tomo (The Housewife's Companion), all journals that combined entertainment and promotional features with helpful hints on practical reforms for improving daily life. New advertising techniques of imaging the commodity were thus allowing the manufacturer to insert his product into the consumer's consciousness (Fig. 6) or to apply it directly onto her body.

Kaō's living mannequins, its marching bands with banner bearers and men dressed as vermilion soap bars, and its show-window designers transformed metropolitan and provincial cityscapes throughout the country. ${ }^{65}$ Japanese manufacturers sought to harness urban space as a promotional venue on which to stage the commodity. Writing in 1931 in the trade journal published by Kaō, Hanbai undō (Sales Movements), Shirokiya department store representative Sasaki Yoshio argued that the "most urgent need for retailers was to go out into the streets." 66

Increasingly, a designed promotional environment surrounded the consumer both indoors and out. The transformation of the city street into a commercial space began long before Kaō's time, back in the Edo period, with decorative signboards, banners, doorway crests, and mobile vending carts. But as technology and mass production transformed life and the urban landscape, they also increased and accelerated the production of advertisements that bombarded the consumer on an everyday basis. A full-page montage-style advertisement for Kaō soap that ran in Asahi graph on October 8,1930 , provides a kaleidoscopic view of the bustling Tokyo metropolis, expressing the fragmented, dynamic nature of experience in the modern city (Fig. 19). With Kaō advertising pillars repeatedly bisecting the frame, the image self-referentially demonstrates advertising's saturation of the modern visual field from the street to the mass media. This matrix of media representations also frames the potential consumer. At the center of the composition walks a kimonoclad woman, a mother holding her child's hand while she carries an infant on her back. The only other figure in the image facing the camera is seen standing in the lower righthand corner, where she anchors the triangulated composition. This flapper-style "modern girl" (moga, as she was commonly called) in her signature cloche hat is easily identifiable, and her presence (although shunted to the side) demonstrates once again Kaō's concern with targeting a range of emerging categories of female social identity.

While most of the photography for the New Kaō campaign has not been attributed, a number of images are reliably credited to the now-famous photographer Kimura Ihee (1901-1974). Although a skilled commercial photographer, Kimura is recognized more for his evocative photographic portraits of celebrated Japanese cultural figures and for his journalistic photographs for illustrated graphic newspapers. ${ }^{67}$ He was also a founding member of the celebrated avantgarde photography journal Kōga (Shining Picture), which ran from 1932 until the end of 1933, spotlighting international developments in modernist photography. Contributors to the group's journal included Hara Hiromu, as well as a number of others working in the commercial sphere. ${ }^{68}$ Yet Kimura was careful to differentiate between commercial and art photography. Unlike a modernist still life, he argued, the commodity could not just be shot "absent mindedly with detachment." It had its own "individuality" and a distinct "social nature" that the photographer needed to understand. Together with its unique points of appeal, the commodity

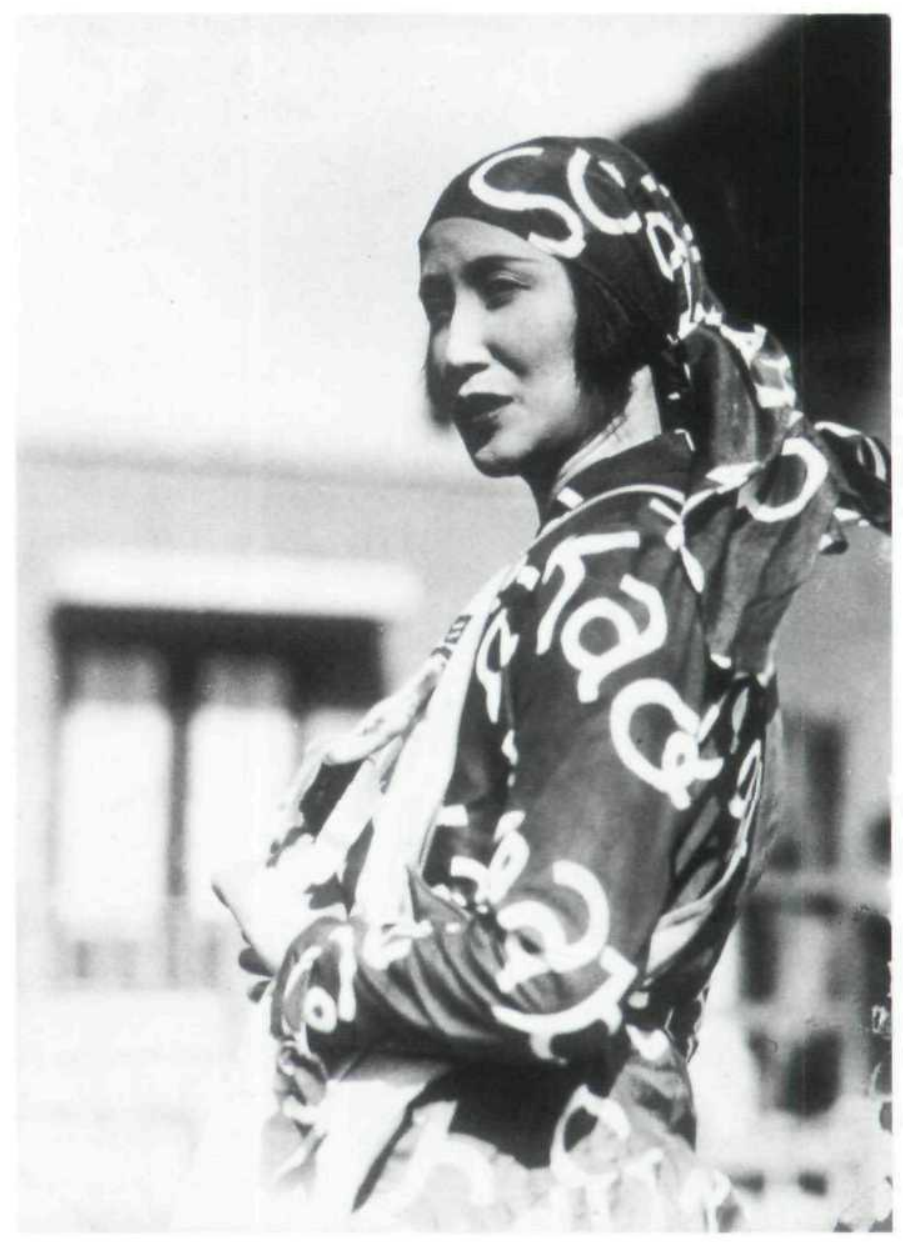

18 Actress Hosokawa Chikako dressed in a Kaō promotional costume, ca. 1931. Tokyo, Kao Corporation 
19 Kaō soap advertisement, from Asahi graph 15, no. 15 (Oct. 8, 1930), Tokyo, Kao Corporation

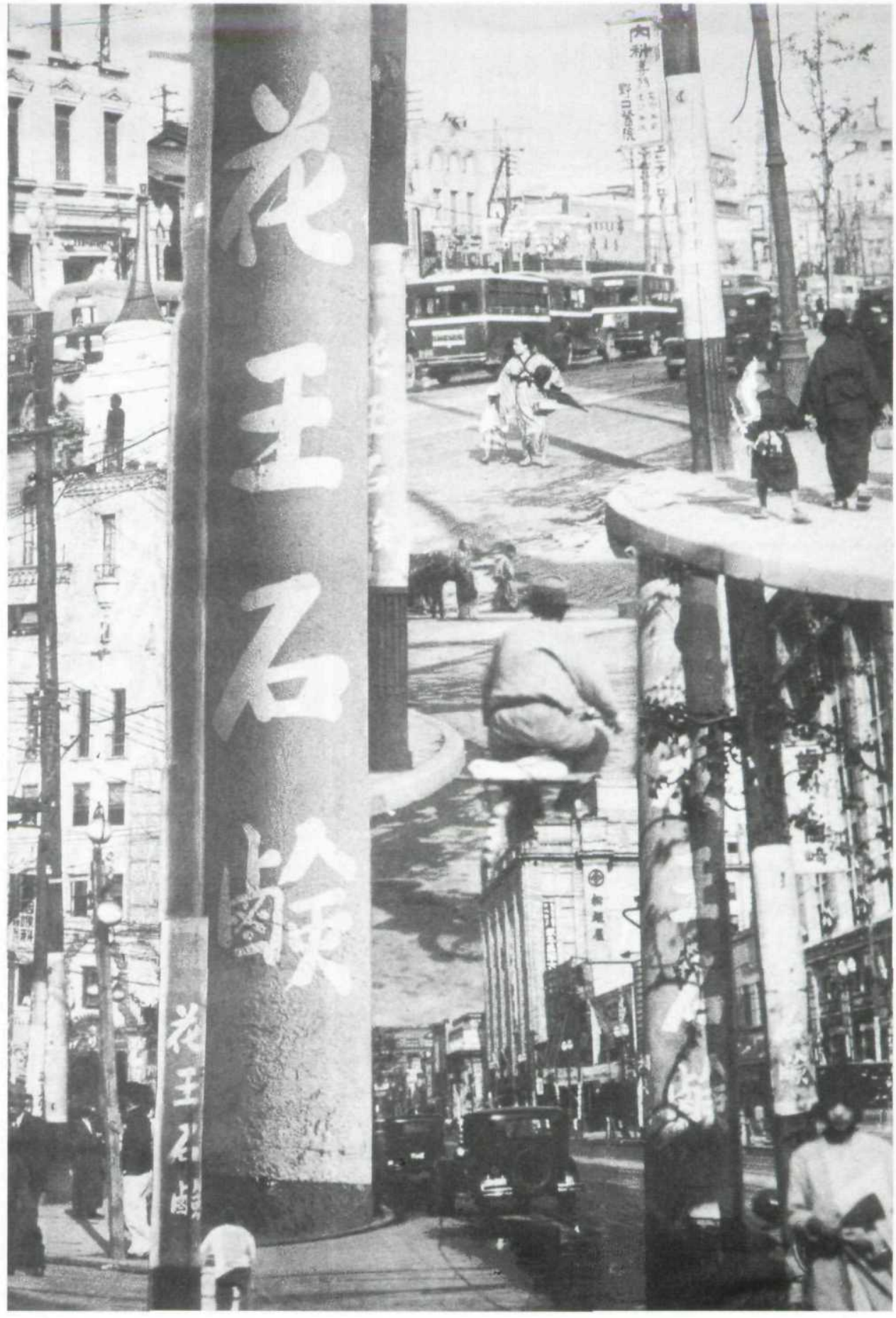

also had an inherent "class nature" that had to be expressed. Detailing his approach to photographing the physical attributes of tube products, in this case Kaō pâte soap in a tube, Kimura reveals the careful technical manipulations of angle, scale, and filtered light that subtly transform the visual impact of the diminutive tube into an ample, gleaming commodity, subliminally justifying the relatively high price of thirty-five sen per tube. A purist who rejected nonphotographic editorial techniques such as airbrushing, he likens the collaborative process between the skilled photographer and the newspaper publisher to the traditional collaboration between the ukiyo-e wood-block print designer, who produced the initial block sketch, and the other craftsmen who carved and printed his design. ${ }^{69}$
The employment of Kimura's photographs in the Kao campaign is significant for more than the high level of craftsmanship it implies. It has a place in the larger history of Japanese commercial photography, as the series was among the earliest to make sustained use of photographs in newspaper advertising. ${ }^{70}$ Part of Ota's visual strategy was to reinscribe Kaō brand-name soap as an everyday item in the mind of the average Japanese consumer. To this end, Kimura's work displayed a series of stark, almost documentary snapshots of industrial laborers, factories, railroads, everyday urban sights (such as laundry hanging on the line, Fig. 20), and common dwellings (some no more than ramshackle shanties, presumably housing the people still displaced after the Kantō earthquake). In the newspaper printing process, the images 


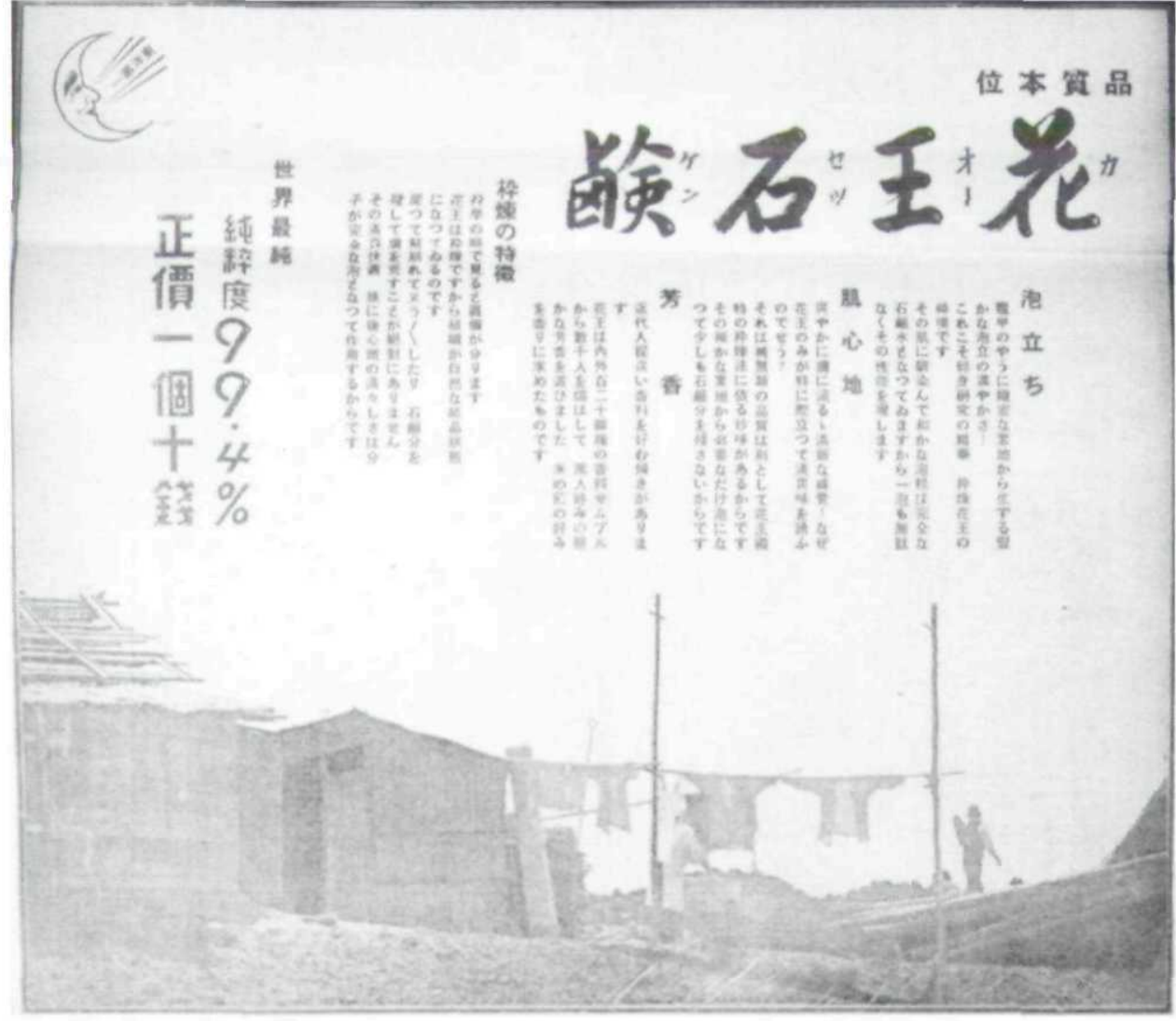

20 Kimura Thee, photographer, Kaō soap advertisement, from Tōkyō asahi shinbun, Apr. 26, 1931. Tokyo, Kao Corporation became slightly washed out and hovered between the documentary and a form of romanticized urban pictorialism, emphasizing the formal composition of the scene over the human element within. In a time when advertising photographs in the print media consisted almost entirely of smiling young women or children holding up products, Kaō's images surely startled the consumer public as well as advertising professionals. $^{71}$

In one newspaper advertisement from the first half of 1931, Kimura, taking his cue from Soviet designer Rodchenko, created a dramatically skewed grid of electrical wires and poles cutting across the metropolitan skyline, an aesthetically pleasing formalist composition that is simultaneously a meditation on the technological nature of modern daily life and, presumably, its attendant grittiness (Fig. 21). A promotional balloon seen in the background pushes its way through the grid pulling a text trailer reading, "New and Improved Kaō." The bubble-shaped balloon humorously reinforces the copy on the right that reads, "Not one bubble wasted."

Use of Kaō soap "From baby's first bath" did not stop with infancy but implied the cultivation of consumers from cradle to grave. This specifically included the important period of their early years, when, of course, children get very dirty. Kimura Ihee's work for Kaō included a humorous series of advertisements of abstracted images on a blank background depicting children blowing soap bubbles, which cleverly used the bubbles to tie together the image of play and cleanliness under the general rubric of domestic hygiene. The image of the bubble further reinforced a crucial sales point for the product: reliable sudsing (Fig. 22). The overall message to mothers implicit in this series was that with the help of soap, their children could play in the dirty modern city without a care in the world.

The use of children in advertising was already a longstanding practice around the world, as it evoked sentimental and nostalgic reminiscences of a simpler, purer, more carefree time of life. Children, particularly babies, commonly appeared in American soap advertisements because manufacturers saw this as an effective means of emphasizing their product's mildness and suitability to delicate tasks. ${ }^{72}$ Kaō advertisements often showed smiling infants in the bathtub or young children washing their hands under copy like "To mothers!" reminding women that the delicacy of their children's skin (and their own) demanded high-quality soap. Images of healthy children undoubtedly also resonated with emerging nationalist ideologies of eugenics that would come to the fore in Japan from the late 1930s.

As was the case with the Kimura series just described, the same advertisements could be placed in mass-market newspapers, general and special-interest magazines, and retail trade journals such as Tokyo komamono keshōhin shōhō (Sundries and Cosmetic Industry News). The design could also be run in a range of sizes, depending on the publication. In newspapers, an ensemble of images and texts on the page framed individual advertisements. Moreover, many of the adjacent news stories amplified the health and beauty themes in Kaō's promotional copy.

Kaō show-window designs spatialized the promotional elements of the company's print advertising on the commodity stage of the retail environment, enticing and structuring the gaze of the passing consumer. One of the greatest areas of imaginative design at the local level, show-window displays 
21 Asuka Tetsuo, designer, and Kimura Ihee, photographer, Kaō soap advertisement at lower left, from Tōkyō asahi shinbun, Mar. 17, 1931. (photo: National Diet Library)

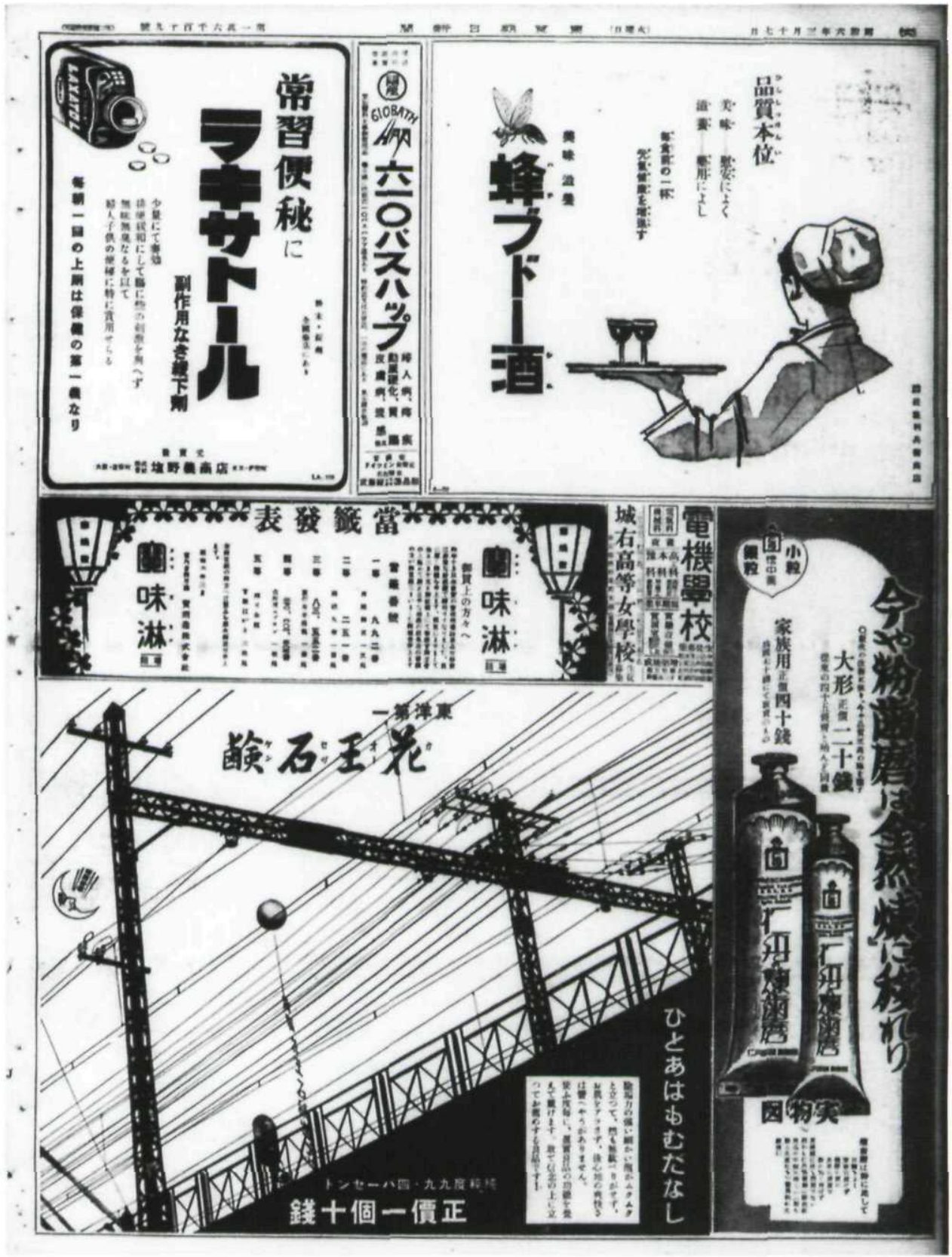

are an ephemeral form that spread throughout the Japanese commercial sphere in the 1920 s but are known only through surviving documentary photographs. Writing in Hanbai undō, Kaō designer Asuka Tetsuo described the company's showwindow designs for "New and Improved Kaō" (Fig. 23) as "expressing Kaō's new dynamic industrial spirit with sounds, moving gears, flashing lights, and the faintest hint of smoke that 'made it seem as if you were looking at the factory process itself in motion. " ${ }^{73}$ Like an intersection of the Constructivist stage designs by Aleksandr Vesnin for The Man Who Was Thursday (1922-23) and the bold cityscapes of Futurist Fortunato Depero's commerical advertisements and theatrical scenography in New York, such displays tried to reproduce the excitement of the urban factory environment in the consumer theater to underline the company's image of productivity and the product's high quality. Moreover, as the text in one display read, this kind of production and, by extension, consumption constituted "soap patriotism."
Another Kaō show window set Hara's new Western-style typography and figures of schoolchildren with anthropomorphized moon faces and Kaō soap backpacks in a pristine bathroom, a dream environment that surely catered to the desires of upwardly mobile Japanese consumers (Fig. 24). Employing the hygienic image of a brightly lit, Western-style tiled bathroom, an incursion that famed novelist Tanizaki Junichirō lamented bitterly in his notorious essay "In Praise of Shadows" on Japanese toilet aesthetics (1937), Kaō aimed at those who aspired to modernize their homes and have private baths, although most Japanese homes did not have private baths until long after World War II. And even in the fervor for modernization, the Western-style bath with foaming bubbles shown in the Kaō fantasy was unlikely to have replaced the beloved Japanese o-furo used primarily for soaking-and collective soaking at that.

Unfortunately, no amount of creative energy expended in the "New and Improved Kaō" campaign was able to counter 


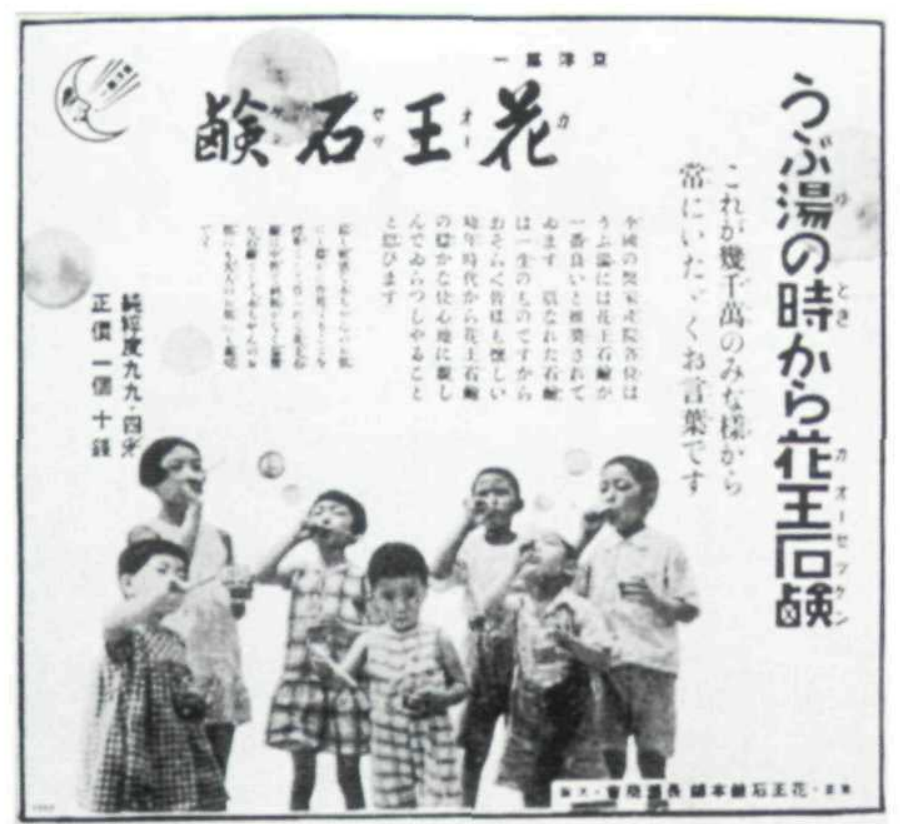

22 Kimura Thee, photographer, Kaō soap advertisement, from Tōkyō asahi shinbun, Oct. 8, 1932. Tokyo, Kao Corporation

the ravages of the Great Depression's worldwide economic downturn. It did not help that Kaō had taken a risky gamble by reinventing itself and incurred enormous expenditures for publicity during the launch years, not to mention the serious profit losses from counterfeit soaps masquerading as Kaō around the country and unexpectedly large amounts of returned stocks of "old Kaō," all of which left the company in perilous financial straits for several years. ${ }^{74}$ It was also quickly apparent to Nagase that the working-class consumers that he and Ōta had hoped to attract were not flocking to Kaō soap, as the reality of the average worker's hygiene situation was far removed from the ideal Euro-American model Kaō followed. Advertising critics even noted that it was difficult at times to pinpoint which classes the company was targeting. ${ }^{75}$ Transitioning quickly from idealism to pragmatism, Nagase asked for Ōta's resignation just three months after the launch of New Kaō and turned over sales and advertising responsibilities to the more conservative Tani Magoroku (also known as Yano Masayo), who had been hired away from the newspaper Yomiuri shinbun to work on Kaō's marketing journal Hanbai undo ${ }^{76}$ Tani's more elitest approach rankled the company workers but proved more practical in business terms, and he continued to work with Asuka and Okuda to build on Ōta's innovative design strategies.

\section{Kaō Advertising Design through the 1930s}

From 1932, advertisements for Kaō soap regularly appeared on the back cover of the armed services journal Umi to sora (Sea and Sky), published by the Japanese navy. A strong modern military was considered an essential pillar supporting the nation. Not surprisingly, military demand for Kaō products grew markedly during Japan's imperialist expansion through the 1930s, notably, its aggressive incursions into China, which culminated in its invasion of that country in 1937, formally commencing the Asia-Pacific War. Kaō's contracts for hospitals and the military lent inestimable credibility to the company's claims of high quality, closely linking the product with technological and scientific modernization. ${ }^{77}$ Images targeting this sector, however, were no less aestheticized than those designed to sell products for the home. Kaō's ads for Umi to sora display dramatic, often highly abstract compositions featuring Japan's cutting-edge military technology paired with the floating bar of soap. In one image from May 1934, the disconnected smoking guns of a navy warship, dramatically viewed from below, project diagonally into a blue sky (Fig. 25). The negative photographic image renders the guns and smoke white against a dark background, causing them to appear as if glowing. A bar of Kaō soap sails into the image from the lower left, implying that it, too, is a weapon being fired at the enemy. Text immediately below the bar reads proudly, "product used by the navy."

Commerce was never far from politics. Both of these dynamic spheres of visual culture were dedicated to the act of persuasion and the glorification of iconic symbols, in one

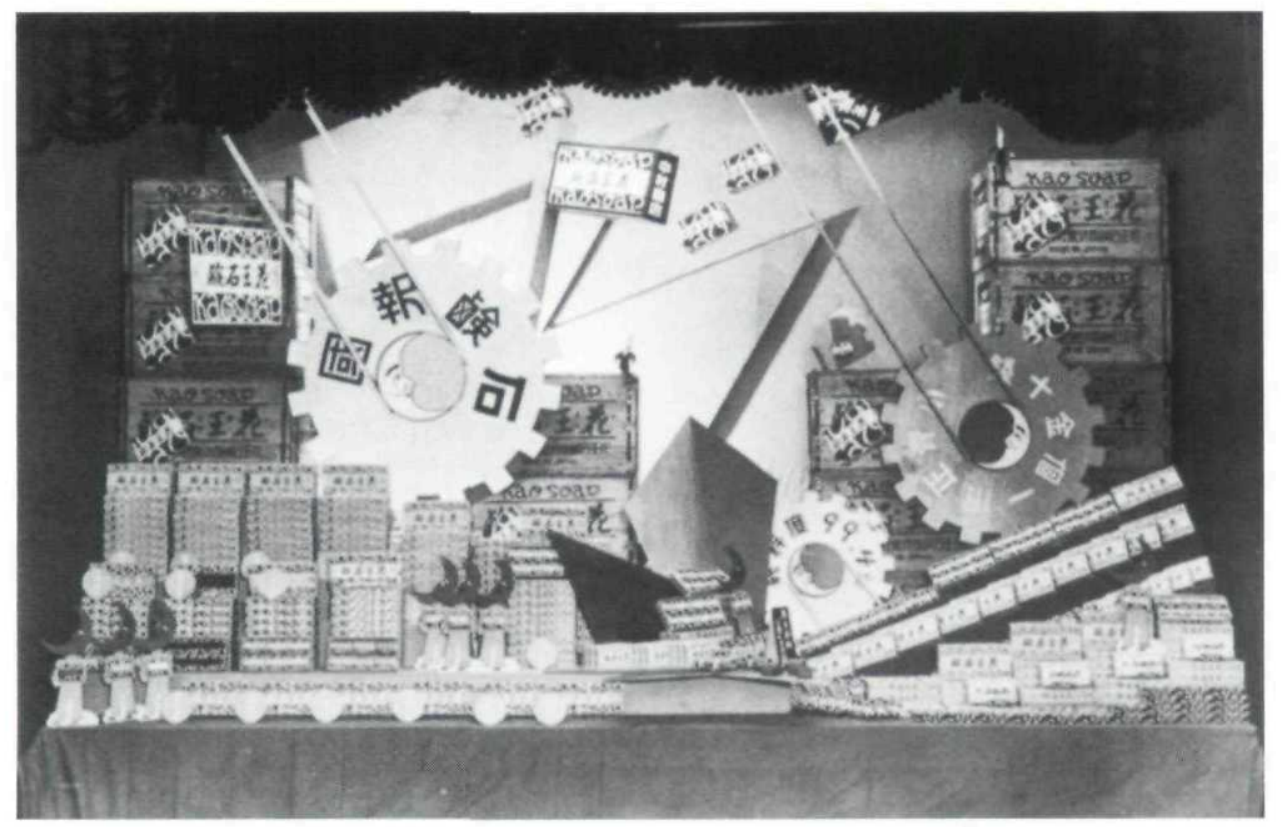

23 Kaō soap show-window display, ca. 1930s. Tokyo, Kao Corporation 
24 Kaō soap show-window display, ca. 1930s. Tokyo, Kao Corporation

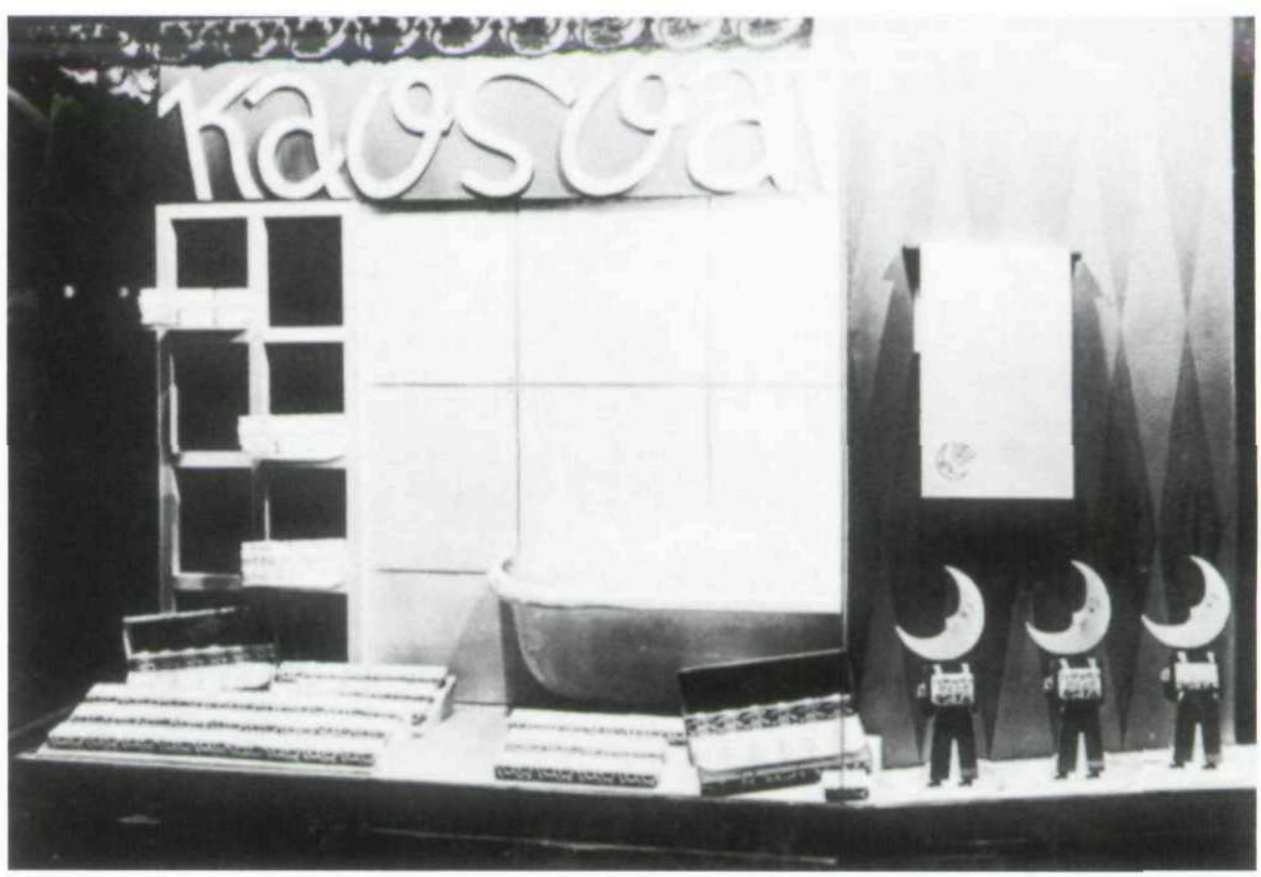

case of political ideology, in the other, capitalist consumption. ${ }^{78}$ In a stunning reformulation of content from the political sphere into the commercial, in this case from the right, a Kaō advertisement for Umi to sora of March 1934 appropriated Willi Ruge's aerial photograph of a zeppelin flying over a 1933 Nazi rally at Berlin-Tempelhof, originally published in the Deutsche Lichtbild photoannual of 1934 (Figs. $26,27){ }^{79}$ The Kaō image boldly substitutes a bar of soap for the mounted political icon of the swastika, denuding the fascist connotations and transforming the gathering into a form of collective worship of capitalism and the commodity. The erasure of the swastika below also elides the pictorial middle ground between sky and earth, flattening out the image into a two-dimensional decorative backdrop for the vibrantly red soap bar, which floats over the picture surface in a surrealistic collage. This kind of superimposition of the product onto the composition to produce a nonnaturalistic photomontage is a vivid example of the inherently composite (collaged) nature of much advertising design, identified by Sally Stein, where disparate images are conjoined and overlapped to construct a visual promotional narrative. ${ }^{80}$

As the changing political winds through the 1930s forced manufacturers to contend with a rise in right-wing nationalism, Kaō advertisements reveal an inventive blurring of left and right, rationality and luxury, and modernism and classicism, exemplified by a 1934 company newspaper advertisement displaying a stylishly dressed modern girl viewed from a dramatically low angle against the backdrop of a starkly lit architectural facade of classical arches not unlike Giuseppe Terragni's Casa del Fascio from the same period (Fig. 28). The advertisement copy exhorts, "The power of soap; Let's drive back bacteria," as the woman stands somberly staring out beyond the picture frame. Here even the highly contentious figure of the modern girl, often associated with hedonistic consumerism and unabashed sexuality, has been taken into the fold of national service, a soldier enlisted in the fight against disease.

While Kaō soap profits increased steadily after the Depres-

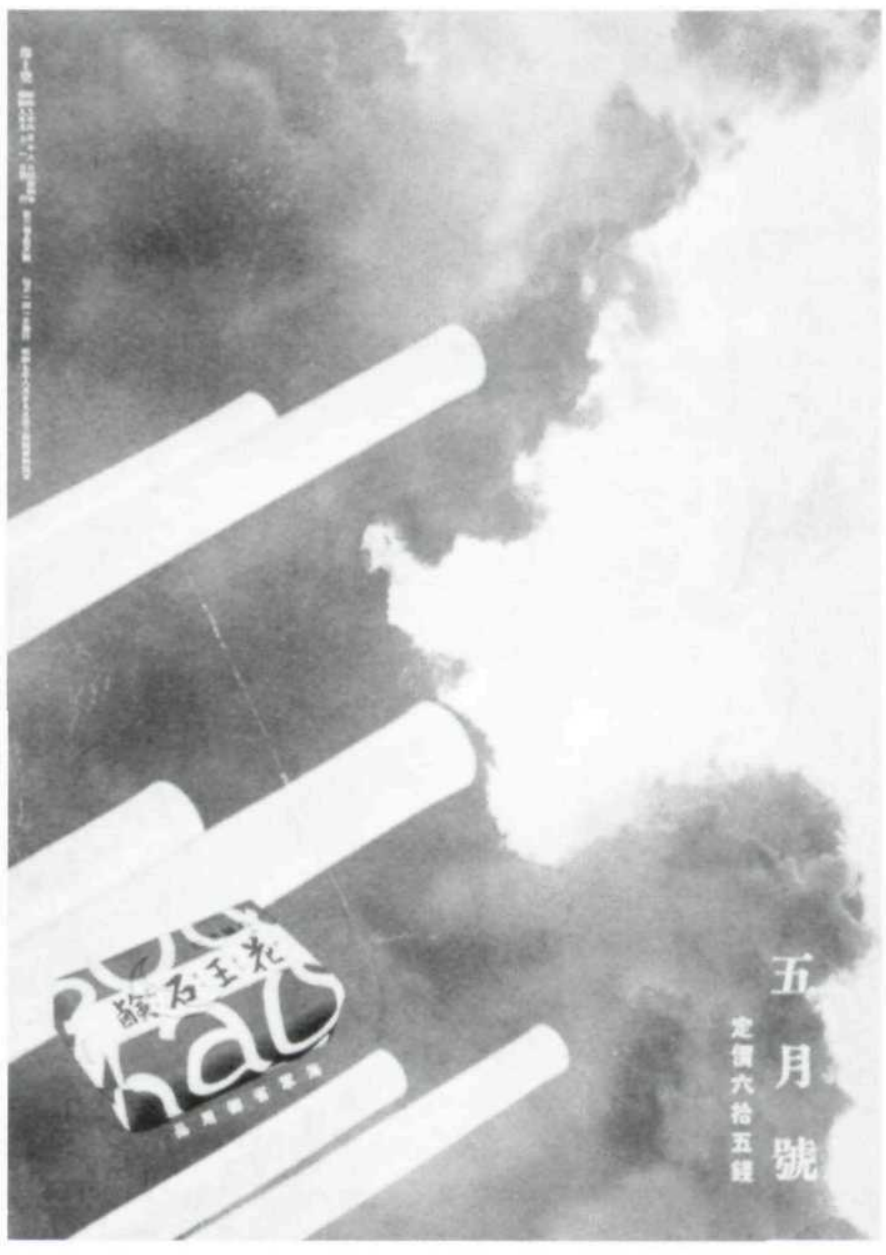

25 Kaō soap advertisement, from Umi to sora [Sea and Sky], May 1934. Tokyo, Kao Corporation

sion, they never returned to their mid-1920s levels, largely because of the price cut of $1931 .^{81}$ It is worth noting that in response to the Depression and falling wages, most Japanese manufacturers cut prices by 25 percent across the board to 


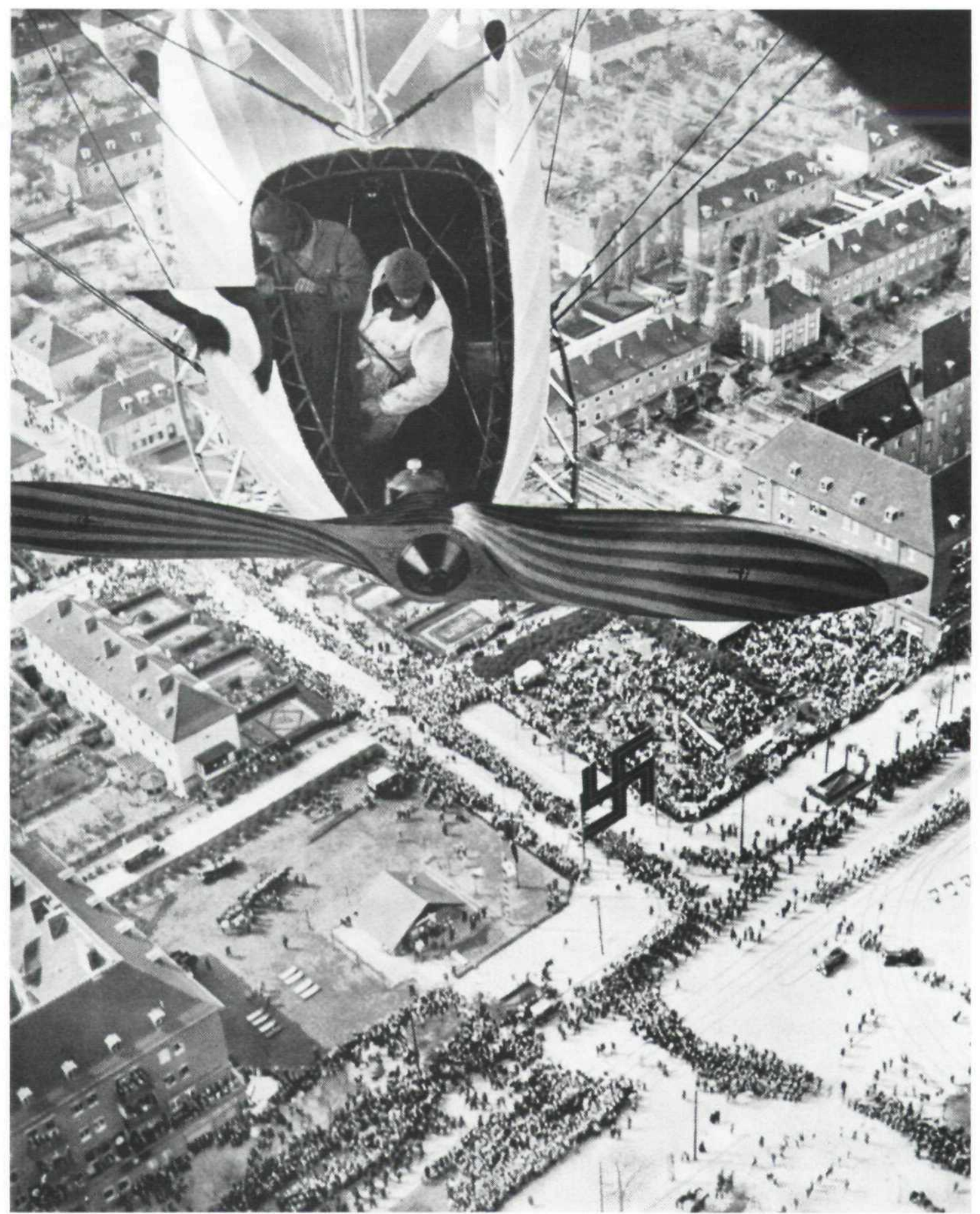

26 Willi Ruge, Zeppelin-Motorgondel, Berlin-Tempelhof, May 1, 1933 (from Deutsche Lichtbild 1934 [Berlin: Bruno Schultz Verlag, 1933], 3)

remain competitive, so Kaō's actions were in line with its cohort. It is also significant that sales for Kaō soap doubled in volume, so the lack of profitability is no indication of advertising effectiveness in terms of increasing product recognition and consumption, which makes it difficult to gauge the overall visual impact or success of the campaign design. Not only did sales double between 1931 and 1937, but also Kaō boosted its share of the market by 1.5 percentage points, with sales reaching their high in $1937 .^{82}$ By that year, Kao soap was consumed at a rate of one bar per twenty-three people per month, an average that had been increasing each year. ${ }^{83}$ The company's stated goal was to increase consumption levels to "one bar of soap per person per month-and-a-half," which Kaō promoted as a perfect balance between hygiene (consumption) and thrift. ${ }^{84}$

Under increasing wartime restrictions from 1937 onward, 


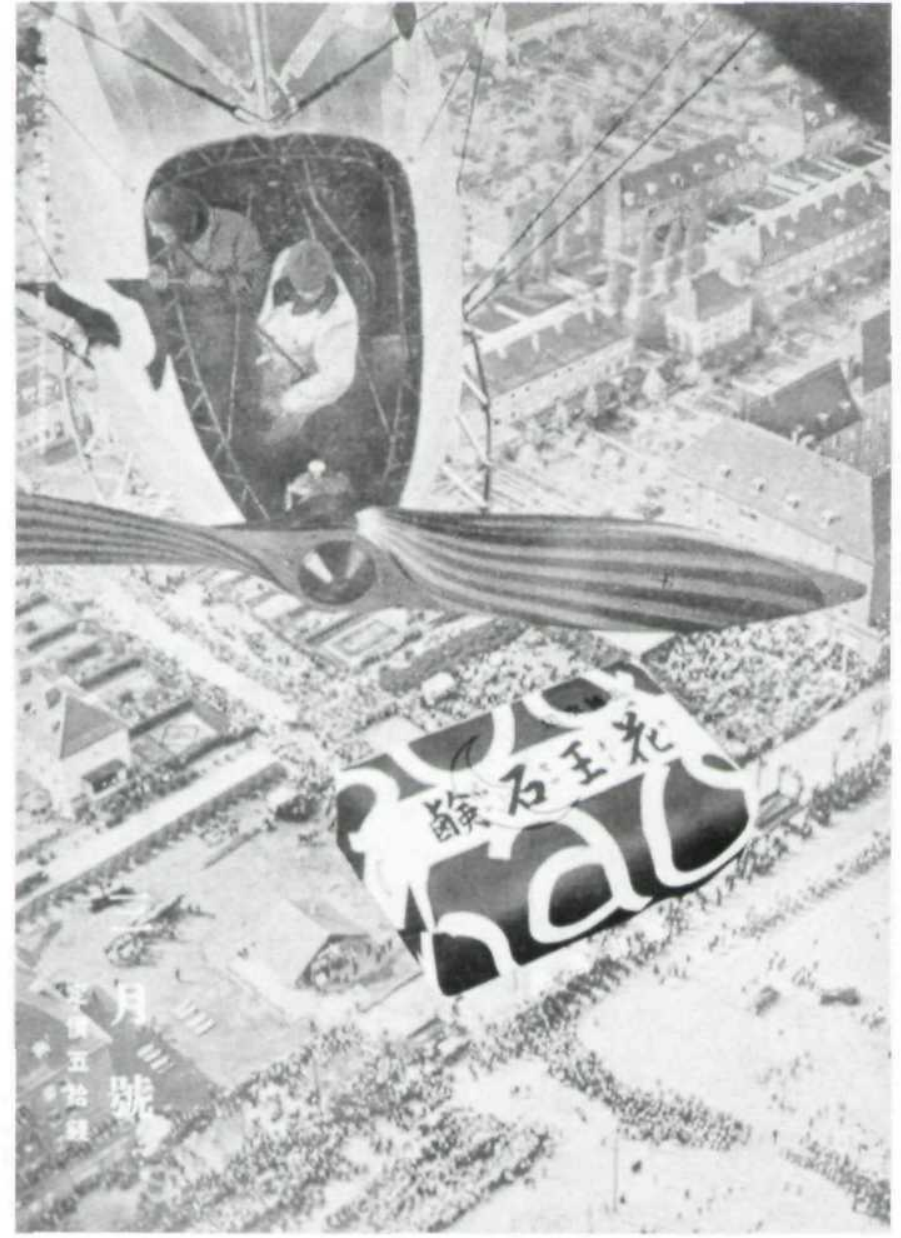

27 Kaō soap advertisement, from Umi to sora, Mar. 1934.

Tokyo, Kao Corporation

Kaō product sales in general continued to increase steadily, peaking in $1940 .{ }^{85}$ The company's connection to state policies of rationalization was reinforced at the beginning of 1937 by the establishment of its Household Science Research Center (Kaji Kagaku Kenkyūjo), which started publishing a promotional magazine in April that year entitled Kaji no kagaku (Household Science). The articles in the magazine examined women's household responsibilities, including mending clothing, cooking, nutrition, child rearing, hygiene, beauty, and laundry techniques, from a "scientific" perspective. The research center held classes in many regional branches, including those in the colonies. In the six years that the courses ran, from 1937 to 1943 , until they were stopped by governmental restrictions, over four thousand classes were held, attended by $1,500,000$ people. ${ }^{86}$

\section{Modernism, Soap, and the Nation}

A ghostly photogram of two overlapping hands emerges from a black background. The text above counsels, "First wash your hands" because "Disease comes not from your mouth, but from your hands" (Fig. 29). ${ }^{87}$ Here the photogram is used to produce an X-ray-like vision. Reinforcing the scientific image, the X-ray simulates the visual penetration of the hands, as if it were a medical instrument. ${ }^{88}$ The luminous whiteness of the spotlighted hands metaphorically implies disinfection, but the defensive position of the extended crisscrossed fin-

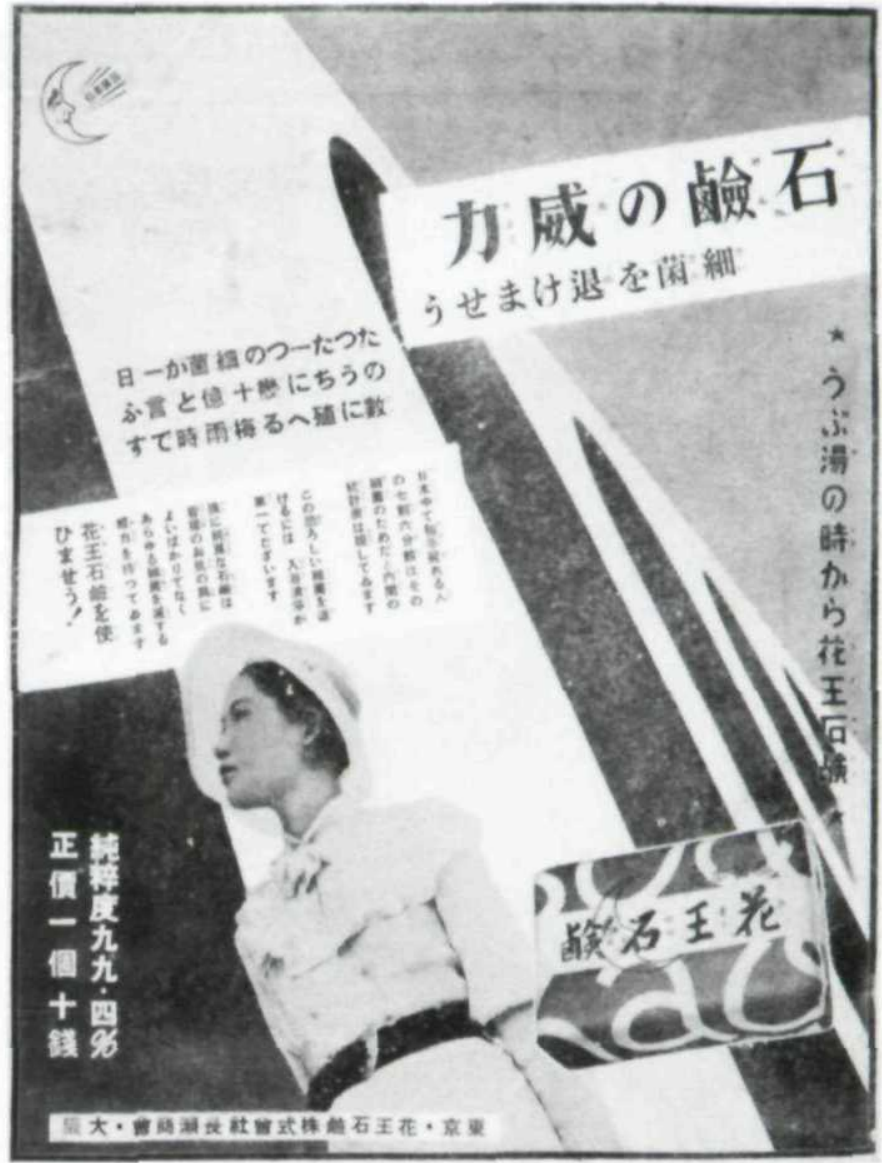

28 Kaō soap advertisement, from Tōkyō asahi shinbun, June 13, 1933. Tokyo, Kao Corporation

gers wards off approaching germs, ominously portending future contamination. Such Kaō corporate advertisements reveal the subtle (and not so subtle) ways in which modernist pictorial strategies could be effectively instrumentalized to commodify new rituals of cleanliness and to aestheticize new consumer products. The fine line separating high art from the market economy was quickly eroding. And whether they employed upbeat pictures of frolicking children or anxious ones of tainted hands, these diverse designs skillfully constructed images of national domesticity in line with gendered discourses on hygiene.

In 1934 the journal Kōkokukai excerpted in English a text by American Frank H. Young from Modern Advertising Art:

Modernism in advertising art, employing new forms, new materials, new color effects and combinations of these, enables the artist to express an advertising message more adequately in the spirit of today.... Modernism, with its simplicity and freedom from tradition, is serving the advertiser well and is giving the advertising artist great opportunity to make use of his creative faculties. ... advertising can and will employ the most advanced technique in art for arresting attention and conveying impressions to modern minds which think and feel in a tempo expressed by the airplane, radio and television, talking pictures and jazz orchestras. ${ }^{89}$ 


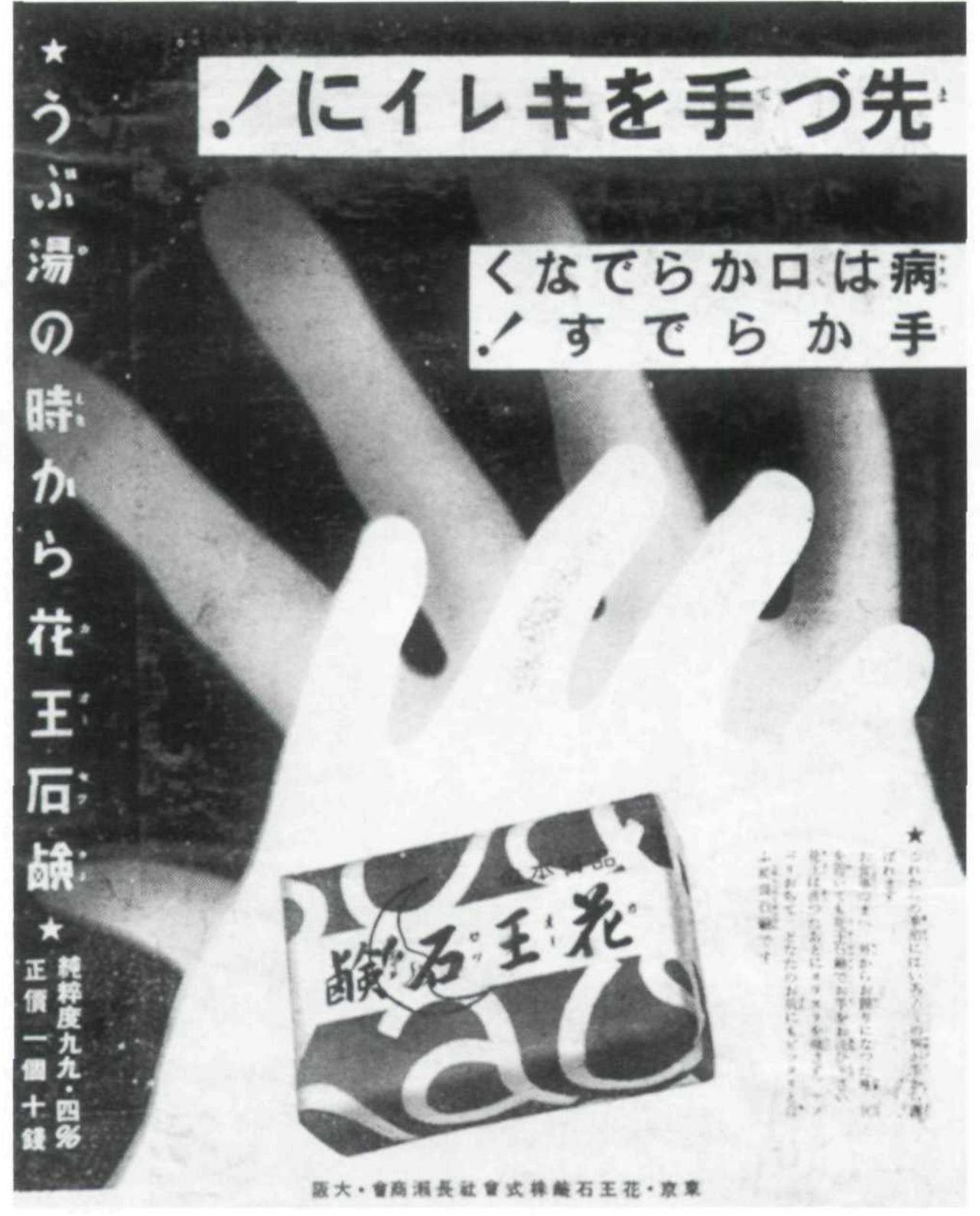

29 Kaō soap advertisement, from Tōkyô asahi shinbun, Mav 28, 1933. Tokyo, Kao Corporation
To gain better "attention value" in a competitive emerging national market, consumer-oriented Japanese companies like Kaō had to rely heavily on the applied aesthetics of advertising design to construct a distinctive corporate identity in the mass media. One critic noted in a review in 1933 that Kaō's advertisements splendidly expressed a "Kaō whiff" that made them immediately identifiable, specifically referring to the company's extensive use of photography, which stood out against the predominantly hand-drawn images of other advertisers. ${ }^{90}$ Kaō's strategy was part of a worldwide upsurge in modernist advertising design that Young observes was also just taking hold in the United States.

In his short commentary, Young admits that lower-class consumers might not appreciate modernist techniques and might perhaps require more conventional approaches in marketing. In a bid to prove the contrary, Nagase, Ōta, and their staff, believing that modernism was exactly what represented a new democratic ideal in Japanese society, used modernist form to appeal to working-class and middle-class con- sumers, maintaining the high-style design of the product to preserve brand loyalty. The lowering of the product's price and the "New and Improved Kaō" campaign democratized Kaō soap, transforming it into a mass-market commodity.

The modern corporation and the commercial designer have long been recognized as powerful cultural producers who sought to reshape daily life through compelling advertisements that would construct consumer identities while directing consumption practices. Health and beauty companies like Kaō plaved a particularly vital role in defining gendered social identities in Japan by inculcating official hygiene regimes. At the same time, by necessity the company's identity was tethered to luxury consumption, as cosmetic soap still catered to an upscale clientele.

By the 1930s, touting the modern virtues of quality, purity, value, and health, Kaō was no longer positioning itself as merely a product manufacturer but instead sought to mold the daily lives of imperial consumer subjects to promote a healthy and productive nation. One ad from the back cover 
30 Kaõ soap advertisement, back cover of Hinode [Sunrise] 2, no. 2 (Apr. 1933). Tokvo, Kao Corporation

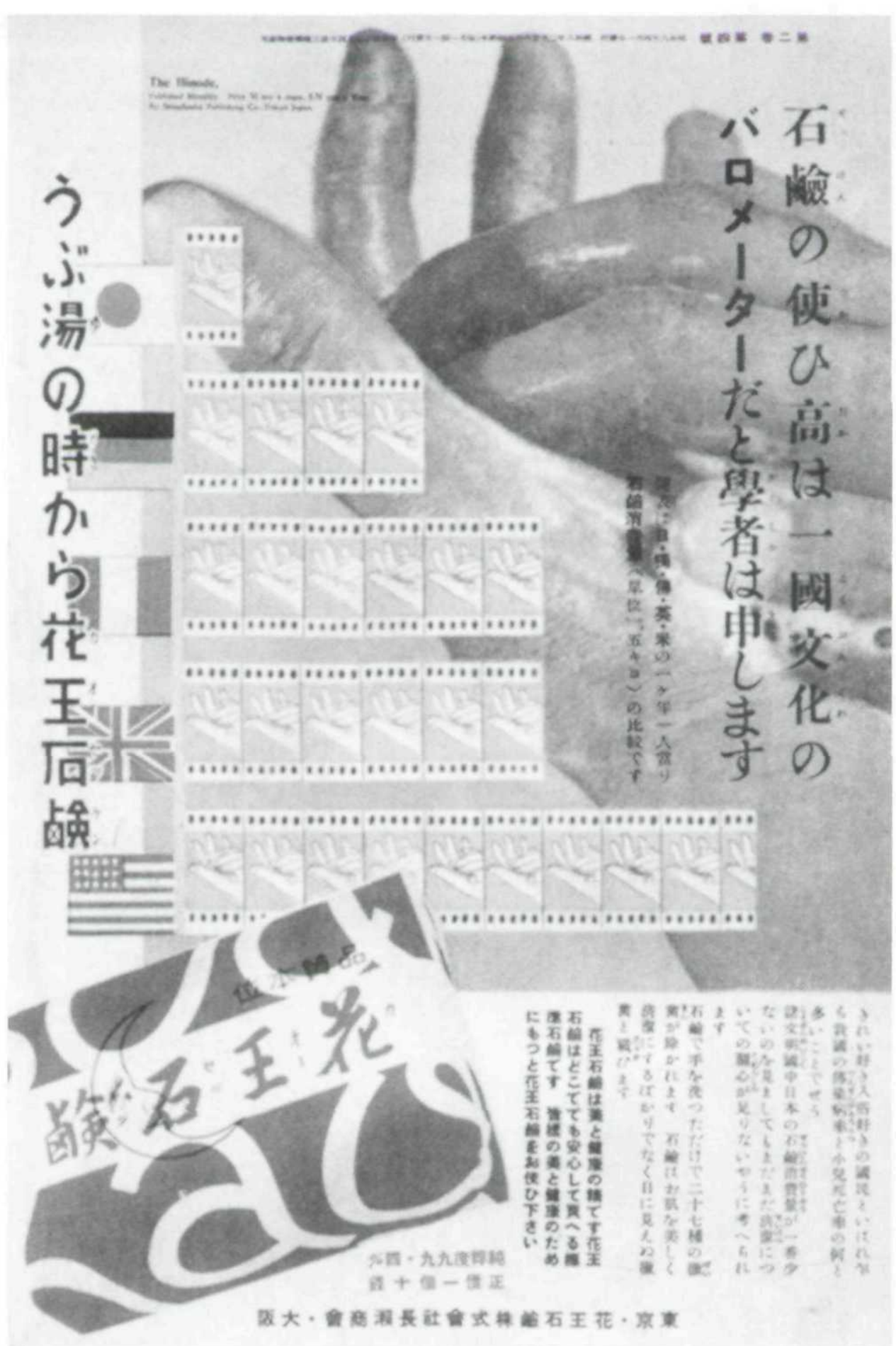

of a 1933 issue of the general-interest magazine Hinode (Sunrise) boldly exclaimed, "Scholars say that the use of soap is a barometer of the culture of a first-world nation," explicitly identifying soap consumption as a sign of a highly developed civilization (Fig. 30). ${ }^{91}$ To emphasize the point further, the designer superimposed bar charts comparing national soap consumption rates using units depicting hands washing onto the same disembodied hand-washing image in the background. This collage aestheticizes rituals of cleanliness and visually reinforces the image of Kaō soap's utility in matters of national hygiene by inserting the product into a seemingly scientific statistical framework. In this image, the United
States is shown representing the highest level of consumption and Japan the lowest. Soap use was thus presented as profoundly connected to national identity and tied to Japan's quest for global status. ${ }^{92}$

To promote proper consumption of its products, the company launched educational initiatives that buttressed state policies. And when the manufacturer provided its retailers with supplies of educational materials like the 1938 pamphlet entitled How to Bathe Your Baby for distribution at the company-sponsored lecture series during national "Hygiene Week," Kaō was promoting daily practices that it hoped would continue well after baby's first bath. ${ }^{93}$ 
Gennifer Weisenfeld is an assistant professor in the Department of Art and Art History at Duke University. Her book Mavo: Japanese Artists and the Avant-Garde, 1905-1931 was published by the University of California Press in 2002. Her current book project is on the history of modern Japanese commercial design [Department of Art and Art History, Duke University, East Duke Building, Box 90764 , Durham, N.C. 27708-07641.

\section{Frequently Cited Sources}

Kā̄shi 100-nen: Nihon Keieishi Kenkyūjo and Kaō Kabushiki Kaisha Shashi Hensanshitsu, Kā̄-shi 100-nen (Tokyo: Kaō Kabushiki Kaisha, 1993).

Rubinfien, Louisa, "Commodity to National Brand: Manufacturers, Merchants, and the Development of the Consumer Market in Interwar Japan," Ph.D. diss., Harvard University, 1995.

Sivulka, Juliann, Stronger than Dirt: A Cultural History of Advertising Personal Hygiene in America, 1875-1940 (Amherst, N.Y.: Humanity Books, 2001).

\section{Notes}

I would like to express my tremendous appreciation to Mark Antliff. Amy Ogata, Simon Partner, Marc Gotlieb, and two anonymous readers for their invaluable comments on this manuscript. I am also deeply indebted to Omura Hidemasa, former section chief of the Kaō Division of Corporate History, as well as the entire division staff, particularly Kubota Ikuko, Yagi Kazuhisa, Mivamoto Mariko, and Hasegawa Noriko. 1 thank Mizusawa Tsutomu for originally introducing me to Kaō. And I also gratefully acknowledge the assistance of Kito Sakiko, Takahashi Yukio, and Kashiwagi Hiroshi. Research for this article was supported by fellowships from the National Endowment for the Humanities, Fulbright-Havs, and the Social Science Research Council. Unless otherwise indicated, translations are mine.

1. Nagase Tomirō's store (Nagase Shöten) opened in the Nihonbashi section of Tokyo in 1887 and became the Nagase Companv Ltd. (Gōshi Kaisha Nagase Shokai) in 1911. In 1925, the company incorporated and was renamed the Kaō Soap Corporation Nagase Company (Kaō Sekken Kabushiki Kaisha Nagase Shōkai). Now simply known as Kaō Corporation (Kaō Kabushiki Kaisha), the company officially romanizes its name to Kao Corporation. For accurate transliteration purposes, in the text I have chosen to render the company and product name Kaō, indicating the long $\bar{o}$ of the second character in the Japanese pronunciation. However, in accordance with the company's wishes, the name is written Kao Corporation in the photograph credits.

2. Exhibitions include 1920 Nendai Vihom-ten, at the Tokvo Metropolitan Art Museum, the Yamaguchi Prefectural Museum of Art, the Hyogo Prefectural Museum of Modern Art, and the Asahi Shinbun (Tokvo: Asahi Shinbun, 1988), 273, 293-95; Geijutsu to kōkoku, Sezon Bijutsukan, Hvōgo Kenritsu Kindai Bijutsukan, and Asahi Shinbun (Tokyo: Asahi Shinbun, 1991), 394-95; and Nihon no grafikku desain, Wakayama Kenritsu Kindai Bijutsukan (Tsū: Wakayama Kenritsu Kindai Bijutsukan, 1996). Kaō advertising design also figures prominently in the three-volume survey history of Japanese advertising compiled by the Tokyo Art Director's Club, Tōkyō Ato Direkutazu Kurabu. Nihon no kōkoku bijutsu: Meiji. Taishō, Shōwa, 3 vols. (Tokyo: Bijutsu Shuppansha, 1967-68)

3. Clement Greenberg, "Avant-Garde and Kitsch," in Clement Greenberg: The Collected Fssays and Criticism, vol. 1, ed. John O'Brian (Chicago: University of Chicago Press, 1986), 5-22. See for example Nancy Troy, Modernism and the Decorative Arts in France (New Haven: Yale University Press, 1991); Terry Smith. Making the Modern: Industry, Art, and Design in America (Chicago: University of Chicago Press, 1993): Beatriz Colomina, Privacy and Publicity: Modem Architecture as Mass Media (Cambridge, Mass.: MIT Press, 1994); Pamela Johnston, Real Fantasies: Edward Strichen's Advertising Photography (Berkeley: University of California Press, 1997); and Maud Lavin, A Clean New World (Cambridge. Mass.: MIT Press, 2001).

Andreas Huyssens's landmark essay "Mass Culture as Woman: Modernism's Other," in After the Great Divide: Modernism, Mass Culture, Postmodernism (Bloomington: Indiana University Press, 1986) opened up the road of interpreting mass culture in terms of gender, and in the vears since its publication many scholars have continued or integrated this mode of inquiry, such as Jackson Lears, Fables of Abundance: A Cultural History of Advertising in America (New York: Basic Books, 1994); and Tag Gronberg, Designs on Modernity (Manchester: University of Manchester Press, 1998).

4. Victoria de Grazia, introduction to The Sex of Things, ed. de Grazia and Ellen Furlough (Berkelev: University of California Press, 1996), 2, 5.

5. The term "rituals of cleanliness" is taken from Sivulka.

6. Narita Ryüichi, "Mobilized from Within: Women and Hygiene in Modern Japan," in Women and Class in Japanese History, ed. Hitomi Tonomura, Anne
Walthall, and Wakita Haruko (Ann Arbor: Center for Japanese Studies, the University of Michigan, 1999), 260. See also idem, "Eisei ishiki no teichaku to "bi no kusari": 1920 nendai, josei no shintai o meguru ikkyokumen," Nihonshi kenky $\bar{u}$, no. 366 (Feb. 1993): 64-89; and idem. "Women and Views of Women within the Changing Hygiene Conditions of Late Nineteenth- and Early Twentieth-Century Japan," U.S.-Japan Women's Journal 8 (1995): 64-86. Narita argues that at this time in Japan the normative notion of the human body was based on the male model, and the female body was assessed in terms of its deviations from this norm.

7. At that time, more than that of any domestic manufacturer, the largest sales of soap in Japan were by the American company Proctor and Gamble, pioneers in the mass production of soap as well as its marketing and packaging. The British soap manufacturer Lever Brothers was also a major player in the Japanese market. It bears mentioning that the regular use of soap for washing the face and body did not take hold in the United States until after the Civil War in the late 1860s. The propagation of soap use in the United States was largely due to Proctor and Gamble's promotion. Kā̄-shi IOO-nen, 6. $\mathrm{I}$ am indebted to Louisa Rubinfien's superb research on the history of Kaō marketing. She notes, 30, that the understanding of "national brand" in the prewar Japanese context was much more limited than our current notion. It usually meant interregional, specifically bridging discrete eastern and western markets, rather than comprehensive national coverage.

8. The per-unit price went up steadily over time, reaching 15 sen in 1931. Kā̄-shi IOO-nen, 25-26.

9. Nihon tōkei kyōkai, ed. Nihon chōki tōkei smann, vol. 4 (Tokvo: Nihon tōkej kyokai, 1988), 474-77. It is important to note that salaries went down precipitously across the board during the Depression.

10. Ibid.

11. From 1892, Kaō joined up with the advertising firm Mannensha, established just two years earlier, buying all the company's Kansai-area advertising through the agency. Kaō also often exhibited or participated in competitions at the various industrial expositions, both nationally and those sponsored by metropolitan governments like Tokyo. Kaō soap consistently won prizes at these expositions. Kaō-shi 100-nen, 30-31, 57.

12. Nagase had well-known doctors endorse his product and commissioned famous writers to write Chinese poetry about it. Ibid., 24.

13. Aramata Hiroshi. Kōkoku zuzō no densetsu (Tokyo: Heibonsha, 1989), 111.

14. Nagase was an early pioneer of advertising strategy and quickly recognized the significance of the newly expanding railroad network for promotional purposes. By 1896, he had installed a Kaō signboard at each station along the Tokaido train line. Kaô-shi 100-nen, 31.

15. It is also important to note that in Buddhist imagery the moon has connotations of purification, and moon viewing is associated with spiritual visualization. I would like to thank an anonymous reader for bringing these connections to my attention.

16. Aramata Hiroshi (as in n. 13), 108-17, has noted two additional hypothetical explanations for Nagase's choice of the crescent moon image: first. that he was inspired by the combination crescent moon and star logo used on one of the early pencil products Nagase Shöten imported to Japan; and second, the semantic connection with moon imagery, as the radical for the character for "skin" (肌), is the moon (月) radical.

17. In 1943, the logo was inexplicably flipped to face toward the left. In the postwar period, for just a few brief years between 1948 and 1953, the company experimented with a feminized version of the logo, but then switched to a more gender-neutral, youthful physiognomy, which has been in use ever since.

18. Nihon tōkei kyōkai (as in n. 9), vol. 1 (1987), 80-81; and Rubinfien, 136

19. The moral suasion campaigns were eventually absorbed into the wartime national spiritual mobilization movement begun in 1937. Sheldon Garon, Molding Japanese Minds (Princeton: Princeton University Press, 1997).

20. The segmentation of the female consumer market from the 1920 s is a complex matter discussed at length in Barbara Satō's recent book The New Japanese Woman (Durham, N.C.: Duke University Press, 2003).

21. Rubinfien, 104.

22. Kaô-shi 100 -nen, 48. Kaō lost over 300,000 ven in assets from the destruction caused by the earthquake. Rubinfien, 238.

23. Rubinfien, 103. A large reduction in imported cosmetic items to Japan and the rest of Asia during World War I and a further reduction after 1930 also greatly benefited domestic producers. Kāo-shi IOO-nen, 46.

24. Kaō soap advertisement, Tōkyö asahi shinbun, May 11, 1932.

25. Ochiai Shigeru, Kaō kōkoku shi, jō-ge gappon (Tokyo: Kaō shiryōshitsukan, 1989), 60.

26. For some examples of contemporary soap advertising designs by Kaō's competitors, see Tōkvō Ato Direkutazu Kurabu (as in n. 2), vol, 2, 108-9, 112 , $114,130-31,206,208-11$. In the 1930s, Shiseido designers also experimented with modernist photography and montage aesthetics in their advertising designs.

27. Tagawa Seiichi, Front: Sensō no gurafizumu (Tokyo: Heibonsha, 1988), 22. 28. Azuma Seiko, "Shinbun kōkoku uraomote," Kōkokukai 6, no. 8 (Aug. 1929): 61.

29. The Japanese Infectious Diseases Prevention Law (Densenbyō yobō hô) promulgated in 1897 was an important milestone in establishing a govern- 
ment policy on public sanitation and hygiene. Subsequent laws and hygiene campaigns sought to inculcate official regimes of hygiene directly into the domestic sphere.

30. As part of the company's structural reorganization, Kaō's advertising section split off from the companv's central administrative division in November 1929, and two months later Okada Hanzō, a well-known advertising theorist, joined the company to head up general planning in the section. Ōta and Okada worked closely together. Kaö-shi lo0-nen, 95.

31. Asuka Tetsuo, Nihon dezain shōshi (Tokyo: Daviddosha, 1970), 19; and Tagawa Seiichi, Kōkoku wa waga shōgai no shigoto ni arazu (Tokvo: Iwanami Shôten, 2003), 10-36, 50-54

32. Tagawa (as in n. 31 ), 38-47.

33. For several years prior to entering the Tokyo School of Fine Arts, Asuka studied in the painting and design division of the Ichikawa Prefectural Industrial School (Ichikawa Kenritsu Kōgyō Gakkō) in his hometown of Kanazawa. After joining Kaō in 1930, he remained with the company until 1951.

34. Four surviving oil paintings by Asuka in the collection of the Ishikawa Prefectural Museum of Art reveal his style in the $1920 \mathrm{~s}$ as a combination of Fauvist and Cubist painterly abstraction.

35. Azuma Seiko, "Shinbun kōkoku baraete," Kōkokukai 7, no. 10 (Oct. 1930): 74 .

36. This work is illustrated in 1920 Nendai Nihon-ten (as in n. 1), 98-99.

37. Kaô-shi 100-nen, 95. Okuda was the principal designer on the highly successful Kaô shampoo campaign launched in 1932, after which he was promoted to section chief of the design division. He continued to work for the company through the war and was instrumental in the resuscitation of Kao soap in the postwar period until his death in 1968.

38. For a discussion of the work of the Barrack Decoration Company, see Gennifer Weisenfeld, "Designing after Disaster: Barrack Decoration and the Great Kanto Earthquake," Japanese Studies 18, no. 3 (1998): 229-46.

39. For an in-depth consideration of one central avant-gardist Japanese art group, see Gennifer Weisenfeld, Mavo: Japanese Artists and the Avant-Garde. 1905-1931 (Berkelev: University of California Press, 2002).

40. I would like to thank Joel Smith for introducing me to the concept of transcultural visual traffic

41. The extant copies of these journals in private collections and institutional archives give evidence of the availability of the material.

42. For a discussion of one important multivolume compendium, edited by design theorist Hamada Masuji, Gendai shōgyō bijutsu zenshü, published 1928 31, see Gennifer Weisenfeld, "Japanese Modernism and Consumerism: Forging the New Artistic Field of Shōgyō Bijutsu," in Being Modern in Japan, ed. Elise Tipton and John Clark (Sydney: Australian Humanities Research Foundation, 2000), 75-98.

43. Tagawa (as in $\mathrm{n} .27$ ), 24

44. For a full account of Hara's career, see the recent work of Kawahata Naomichi, Hara Hiromu to bokutachi no shin kappanjutsu (Tokyo: Transart. 2002)

45. Tagawa Seiichi, Shimi moku moku (Tokvo: EDI Archive 4, 1998), 28.

46. Kaō-shi 100-nen, 96.

47. The company's earliest advertising efforts concentrated on newspapers, allocating over 70 percent of its total annual advertising budget to this area of the media. Only later did the company broaden its reach to include generalinterest magazines. Kaō-shi 100 -nen, 30,119 . In the early years of the company, around 1890-91, Nagase is believed to have spent close to 44 percent of the company's annual profits on newspaper advertising. Ochiai (as in n. 25), 66 .

48. Rubinfien, 21.

49. The Kaô company history indicates that advertisements ran in seventeen newspapers around the country, twelve in northeastern Japan, two in western Japan, and the remaining papers scattered in other regions. Advertising was largely concentrated in several major news organizations. For Tokvo it was Jiji shimpō and the Tōkyō asahi shimbun, in the Kansai area it was the $\bar{O}$ saka asahi shinbun (which became the Asahi shinbun in 1889) and Ósaka mainich shinbun (which became the Ōaka Niptō in 1888). Kaōshi 100-nen, 30-31.

50. The catchphrase "99.4\% pure" was taken from Proctor and Gamble's copy for Ivory soap, which was used as a demonstration of its purity and high quality. Kā̄shi 100-nen, 102.

51. Kā̄-shi 100-nen, 95.

52. A practitioner, theorist, and educator who taught photography at Nihon University for most of his career, Kanamaru was closely attuned to cultural developments abroad, particularly in Germany and the Soviet Union. He amassed a sizable collection of foreign design trade journals. Kanamarn owned numerous issues of the USSR in Construction: nos. 1-4, 5 (English and French), 6, 10, 11, 12 (1931), 8 (French, 1932), 10 (1932), 7 (July 1933). For an overview of Kanamaru's career and his copious publications, see the Nihon University Photography Division Festschrift published in his honor, Kanamanu Shigene Sensei koki kinen (Tokyo: Kanamaru Shigene Sensei koki kinen jimukyoku, 1974). Kanamaru's entire private library collection is now archived at Nihon University. I would like to take this opportunity to express my profound appreciation to Kaneko Ryuichi for introducing me to this archive and to Professors Hara Naohisa, Takahashi Norihide, and the entire staff and faculty of the photography division of Nihon University, who generously allowed me to study the Kanamaru materials.

53. Lenin, quoted in Smith (as in n. 3), 4. European politicians, thinkers, and commercial enterprises with allegiances ranging across the political spectrum adopted the principles of scientific management and Taylorism, which sought to achieve maximum prosperity for employer and (purportedly) employee through systematizing and rationalizing company organization. This included such important concepts as the assembly line. Tavlorism has subsequently been criticized, most vociferously by the political left outside the Soviet Union, for alienating and dehumanizing workers. For a discussion of the appeal of scientific management to the left and right, see Charles Maier, "Between Taylorism and Technocracy: European Ideologies and the Vision of Industrial Productivity in the 1920s," Joumal of Contemporary Histony 5, no. 2 (1970): 27-61; and Jeffrey Herf, Reactionary Modernism (Cambridge: Cambridge University Press, 1984)

54. Leah Dickerman, "The Propagandizing of Things," in Alexandr Rodchenko (New York: Museum of Modern Art, 1998), 66

55. The catchphrase "close friend" appeared in a 1929 Kaō newspaper advertisement featuring smiling male workers arm in arm.

56. Smith (as in n, 3), 9. My reading of Kaō's advertisements in the colonies is limited to the material in the company archives in Japan, as I have not had access to publications from other parts of Asia.

57. I would like to thank Hae-Young Kim for her invaluable assistance in translating this text.

58. Both Anne McClintock and Juliann Sivulka have convincingly argued that in the Euro-American context, soap and the discourse of cleanliness were fundamentally implicated in the ideologies of imperialism and white supremacy. See Anne McClintock, "Soft-Soaping Empire," in Imperial Leather (London: Routledge, 1995), 207-31.

59. Mariko Tamanoi argues that Japanese social reformers of vastly differing backgrounds from the political right and left focused on the factory woman's body as a site necessitating moral and physical reform to ensure the continued prosperity of the nation. Unhealthy working conditions took their toll on women's health, and this had devastating ramifications for their work and procreative productivity. Tamanoi, "Japanese Nationalism and the Female Body: A Critical Reassessment of the Discourse of Social Reformers on Factory Women," in Tonomura et al. (as in n. 6), 276, 282-83.

60 . The expressiveness of hands in foreign and domestic advertising was a topic discussed in Japanese trade journals. See for example Shinbō Tamihachi, "Kōkoku ni arawareta te no hyōgen," Kōkokukai 11, no. 6 (June 1934) 69-73. Shinbō was emploved in the Kaô advertising division. Traditiona Buddhist rituals and imagery also prominently featured symbolic hand gestures (mudra), which were widely known in Japanese popular culture. 1 am again grateful to an anonymous reader for bringing this to my attention.

61. Deparment stores listed as part of this campaign were Ginza Matsuzakaya, Nihonbashi Shirokiva, Ueno Matsuzakava, Gotanda Shirokiva, and Yokohama Sōgōya.

62. A number of European and Russian avant-garde groups had experimented with promotional fashions, including the Russian Constructivists and the Italian Futurists.

63. Gronberg (as in n. 3), 42.

64. Ibid., 44

65. Surviving photographs in the Kaô company archives document these promotional parades.

66. Rubinfien, 341.

67. For a recent historical survey of Kimura's work, see Tokyōto shashin bijutsukan, Kimura Thee no sekai (Tokyo: Tōkyōto shashin bijutsukan, 1992). The conspicuous absence of Kimura's extensive work in commercial advertising in this volume is indicative of the still-problematic status of commercial photography vis-à-vis the more respected fields of art photography and photojournalism.

68. Originally published by Shürakusha, Köga has been republished in facsimile form. The journal is widely acknowledged by photo historians for its advocacy role in bringing modernist photography to Japan. lizawa Kötarō, Kōga (Tokyo: Fukkokuban Kōga Kankôkai, Hatsubai Gakkō Tosho Shuppan. 1990)

69. Kimura Ihee, "Kōkoku shashin sakuseihö," Kōkokukai 10, no. 9 (Sept. 1933): 52-55

70. Tagawa (as in n. 27), 24.

71. While there is surprisingly little specific reference to the launch of the New Kaō campaign that I have found in contemporary trade journals, Kaô advertising in general was a regular topic in Kökokukai. Critics often tended inexplicably to focus on the less dynamic examples of the company's advertising production. This is perhaps a valuable reminder of the varied visua interest of the company's voluminous advertising production over the decades. One Kōkokukai critic notes that Kaō design was typified by the incorporation of photography and that this made the company's advertising style quickly identifiable. He writes, "I believe that I am not the only one who intuits that this is a Kaō advertisement just by first impression." Naruse Hiroshi, "Shinbun kōkoku no kaibō: Kaō Sekken," Kōkokukai 9, no. 7 (1932): 74-76. Moreover, the Japanese design community has retrospectively acclaimed Kaô for its advertising work in the late 1920s and 1930s. Fushimi Fumio, Nihon no kökoku shashin 100-nenshi (Tokyo: Kodansha, 1986), 64; and Nakai Köichi, Comãsharu foto, Nihon shashin zenshū, vol. 11 (Tokvo: Shogakukan, 1986), 7, 10-11.

72. There was also a famous British image of a young child by Sir John 
Everett Millais entitled Bubbles that was used for a Pears soap advertisement in 1888 and soon became a classic. Sivulka, 88-96.

73. Asuka Tetsuo, "Shō uindō o kataru," Hanbai undō, no. 5 (May 1931): 14-15, trans. in Rubinfien, 338 n. 189. Another variation on the Kao showwindow design described by Asuka is pictured in Kökokukai 8, no. 3 (Mar. 1931): 37 .

74. Rubinfien, 4.

75. Aka Enpitsu ko [pseud.], “Kōkoku sunbyō," Kōkokukai 10, no. 6 (June 1933): 28.

76. In one of his few signed statements in Nagaseman, Ôta wrote a humble and heartrending farewell address directly to the employees indicating his deep remorse about not succeeding with the campaign as he had hoped. Tagawa (as in n. 45), 36-37. Ota returned to do work for Kao in the postwar period in the $1950 \mathrm{~s}$.

77. Kä̈-shi 100 -nen, 30.

78. Benjamin Buchloh's early article charts the interplay between the spheres of political propaganda on the left and right as well as the overlapping strategies of political and commercial forms. Buchloh, "From Faktura to Factography," in The Contest of Meaning, ed. Richard Bolton (Cambridge, Mass.: MIT Press, 1992), 49-80.

79. A few years earlier, Kōkokukai ran an article on the incorporation of a visiting German zeppelin into Japanese advertising and the great appeal of this image and its various tie-ins. Azuma Seiko, "Tsebegô to shinbun kōkoku," Kökokukai 6, no. 9 (Apr. 1929): 62-65. I am grateful to Joel Smith for providing me with information on the Deulsche Lichtbild image.

80. Sally Stein, "The Composite Photographic Image and the Composition of Consumer Ideology," Art Journal 41, no. 1 (spring 1981): 39-45.

81. Throughout the period of the Depression and sharp dips in profits, the company continued to sponsor innovative design, advertising. and marketing techniques, adding new products to the New Kao line to try to ride out the crisis in the market. This included Tsubame (Swallow) soap, Kaō pâte cream soap in a tube, and especially the enormously popular Kaō shampoo. Kaō shampoo was the product that introduced the term "shampoo" into common parlance in Japan, Kaō 100-nen shi, 105.

82. Rubinfien, 374.

83. Ibid., 378 ,

84. Ibid., 347 n. 209.

85. Kañ-shi 100-nen, 134. In the early 1930s, before the full outbreak of the war with China in 1937, Kao's overseas operations were largely limited to Southeast Asia. These operations developed from gradual exports to setting up operations abroad and were motivated by both the search for new markets and accessibility to raw materials. A brief chronology of the company's overseas operations is as follows: 1932, Seoul office opened (became full branch office in 1943); 1934, Manchukuo office; 1938, Taipei office; 1938, Seoul and Manchukuo office consolidated in Dairen: 1939. Shanghai office: 1939 and 1940, Kaō subsidiaries were established in Shanghai and Manchukuo respectively. Kaō even took over Proctor and Gamble production factories in Surabaya in Indonesia. Kaồ-shi 100-nen, 156-57.

86. The research center also helped launch a national advertising campaign established to contribute to the wartime "assistance movement." The work produced, known as "assistance advertisements," was similar to government propaganda. Kǟ-shi $100-n e n, 156$.

87. Tôkyō asahi shimbun 1934

88. The applicability of photograms to advertising is briefly discussed by Murota Kurazō in "Reiautoman to kōkoku shashin no shivōhō," Kōkokukai 9. no. 2 (Feb, 1932): 59. Photograms were championed by renowned photographers Man Ray (Rayograms) and László Moholy-Nagy, who also advocated their use in advertising. The article by Moholy-Nagy "Fotoplastische Reklame" (Photoplastic advertising) in the widely circulated 1926 Bauhaus special issue of Offset-Buch- und Werbekunst 3, no. 7 (1926): 386-92, featured photograms by the author and Man Ray used in advertising design.

89. Frank H. Young, "Modern Advertising Art," Kōkokukai 11, no. 7 (July 1934): 76.

90. Aobun Doko [pseud.], "Kōkoku sunbyô," Kōkokukai 10, no. 3 (Mar. 1933): 29.

91. American soap manufacturers like B. T. Babbitt connected the notions of cleanliness through soap use and civilization in advertising copy as early as the $1890 \mathrm{~s}$. Babbitt's promotion for Best soap on a direct-marketing trade card ran, "Soap for All Nations," "Cleanliness is the scale of civilization." Sivulka, 103.

92. A related newspaper advertisement from the same year that similarly employs bar charts to show Japan's low standing in terms of soap use reveals the economic rather than moral subtext of this hvgiene discourse. "This is the truth!" it exclaims. "Sickness is the most uneconomical!" This advertisement is pictured in Aka Enpitsu ko (as in n. 75).

93. Rubinfien, 358. 
Copyright of Art Bulletin is the property of College Art Association and its content may not be copied or emailed to multiple sites or posted to a listserv without the copyright holder's express written permission. However, users may print, download, or email articles for individual use. 